\title{
Az agglomerációk jelentóségének változása az államszervezés és a városi kormányzás szempontjából
}

\section{The changing significance of agglomerations in light of state spatial organisation and regional governance}

\author{
SOMLYÓDYNÉ PFEIL EDIT
}

KULCSSZAVAK: agglomeráció, városrégió, nagyvárosi kormányzás, közigazgatási reform, versenyképesség, globalizáció, sokszintú kormányzás, államfelfogás

ABSZTRAKT: Az agglomerációk mint a társadalmi és gazdasági tevékenység súrúsödési területei a szabályozó állam szempontjából a 19. század vége óta jelentőséggel bírnak. A tanulmány a nagyvárosi térségek intézményesitésének folyamatát, annak kiváltó okait és céljait elemzi három történeti időszakban. Az intézményesités mikéntje feltétlenül összefügg az adott korszak állammodelljével (fordista vagy jóléti, posztfordista állam), sőł a területi hatalomgyakorlás struktúráinak változásával is. A városmagnak és vonzáskörzetének együttmúködése eleinte közigazgatás-szervezési és területi tervezési kérdésként jelentkezett, az elmúlt két évtizedben azonban nyilvánvalóvá vált, hogy e tereknek városrégiókként való értelmeződése a nemzetállamok gazdasági versenyképességének egy kulcselemét testesíti meg a globalizáció és az új regionalizmus keretei között. A nagyvárosi kormányzásban a hagyományosan hierarchikus társadalomirányítás mellé léptek a partnerségi hálózatok, amelyek egyrészł beékelődnek a többszintú kormányzási rendszerbe, másrészł horizontálisan a lokalitás elönyeire és az önigazgató struktúrákra építve szubnacionális szintú cselekvési egységet (teret) képeznek.

KEYWORDS: agglomeration, city region, metropolitan governance, public administration reform, competetiveness, globalisation, multi-level governance, rethinking of the state

ABSTRACT: As hubs of social and economic activity, agglomerations have played a significant role from the point of view of the regulatory state since the end of the 19th century. The present study investigates the process, underlying causes and objectives of the institutionalisation of metropolitan areas during three distinct historical periods. The method of institutionalisation necessarily correlates with the state model characteristic of the given period (welfare or post-Fordist state) as well as with the evolution of territorial power structures. Initially, the idea of city-suburban cooperation emerged in the domains of public administration and spatial planning, yet the past two decades have demonstrated that the qualification of such spaces

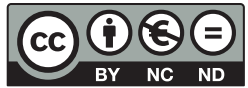


as city regions constitutes a key factor of national economic competitiveness in the framework of globalisation and new regionalism. In metropolitan governance, we can witness the emergence of partnership networks besides the traditional hierarchical control of society, which on the one hand, are integrated into multilevel governance systems, and on the other hand, in horizontal terms serve as subnational units (areas) of action relying on the advantages locality and selfgoverning structures offer.

\section{Bevezetés}

A városok és városi térségek jelentősége egyre növekszik a globális gazdasági folyamatok és a nemzetállami politikák keretei között éppúgy, mint az Európai Unió kohéziós politikájában. A modern városkutatásban és -tervezésben város és vonzáskörzete többé már nem a központ és periféria viszonyát kell, hogy jelentse, hanem egységes teret, amely a korábbi koncentrikus körökbe tagolt tér helyett - mely a központból kiindulva fejlődési lejtőként értelmezte a településgyürüket a vonzáskörzet határa irányában - hálózatos és mozaikszerű struktúrákból áll, mert ezekben helyük van a mikrotérségi települési és társadalmi szerkezeteknek és különbségeknek.

A város, az „urbánus” már nem csupán a szükséges rossz fogalmával azonosítható, ehelyett pozitív fejlesztési erőt testesít meg a társadalom jóléte szempontjából (Jørgensen, Aerø 2008). Idézhetjük az EU-t is, amelynek regionális politikájában fokozatosan legalizálódott az urbánus szemlélet, s mára elismerést nyert, hogy a városok a növekedés és az innováció hordozói. A Lipcsei Chartaként ismertté vált politikai dokumentum egyenesen úgy fogalmaz, hogy az európai területi fejlődés zálogát a városok jelentik (Territorial Agenda of the EU, 2007). Az 1990-es évtizeddel kezdődően az EU keretei között a városok kiemelt figyelmet kapnak, egyfelől mint a társadalmi és környezeti problémák csomósodási helyei, másrészt mint a gazdasági potenciál növelésének eszközei.

Az urbánus szemlélet ismételt hódítása során a városrégióknak, agglomerációknak kitüntetett szerepük van, mivel szervesült térként a gazdaságfejlesztés meghatározó egységeivé váltak. Az agglomerációk a társadalmi és gazdasági tevékenységek sűrüsödési pontjai, amelyekben a városmagnak és környékének működése a legteljesebben összefonódott. Ebben a térben a közigazgatási fragmentáltság leküzdésére a kezdetekben még megfelelő eszközt jelentettek az adminisztratív reformok és az önkormányzatok közötti horizontális együttműködések, azonban a gazdasági környezet változásával szükségessé váltak olyan állami intézkedések, amelyek hozzájárultak a bürokratikus akadályok és a tradicionális közigazgatási határok feloldásához. A várostérségi együttműködés lokális dimenziója regionális, nemzeti, illetve nemzetközi léptékü cselekvési térré fejlődött. Míg az 1960-70-es években az agglomerációk társadalmiszolgáltatási képességének mint funkcióképességnek a megteremtése volt a 
cél, amit úgynevezett agglomerációigazgatási szervezetek létrejötte fémjelzett, ma már a regionalizáció fogalmi körében értelmeződo” városrégiókról mint modern gazdasági telephelyekről beszélhetünk. Ez utóbbiak esetében kifejezetten a kormányzási képesség minősége a tét. A nemzeti kormányoknak azonban továbbra is feladatuk, hogy a városi térségek pozícióit pénzügyi és policy-eszközökkel javítsák, elősegítve egy olyan stabil környezet létrejöttét, amelyben a városok maguk alakíthatják külpolitikájukat. ${ }^{1}$ Eközben történeti nézőpontból végigkísérhető az államnak mint szabályozó, ellenőrző és szervező hatalomnak e téregységekhez füződő változó intenzitású - hol ösztönző, hol akadályokat állító - viszonyulása.

Az agglomeráció fogalma a normatív állam szemszögéből abszolút fontossággal bír (a közigazgatás-szervezés és a gazdaságfejlesztés szempontjából egyaránt), tekintettel arra, hogy az agglomeráció az egymás közelében, egy térségben sűrüsödő gazdasági tevékenységek összessége, amely lehet iparági körzet vagy egy nagyváros és vonzáskörzete (Lengyel 2003, 48.). Az agglomerációkhoz kapcsolódó előnyök között időben változó, újabban statikus és dinamikus előnyök különböztethetők meg, mely utóbbiak között a globális versenyben kimutatható sikeresség a tudás létrehozásához és helyi elterjesztéséhez szükséges lokális háttérből is fakad. Ehhez kapcsolódik az a felfogás, hogy az innováció forrásai leginkább a tágabb értelemben vett társadalmi és területi struktúrákban keresendők, vagyis a társadalmi és gazdasági intézmények agglomerációjában és szinergikus hatásaiban, amelyek összeforrtak az innováció technológiai infrastruktúrájával (Lengyel 2003, 48-53.). A növekedési pólusok modellje szerint a dinamikus ágazatokat tömörítő központok lényegében olyan növekedési pólusok, amelyek agglomerációs hatások útján növekedési hatást gyakorolnak a környező településekre. A növekedési pólus maga egy centrumtelepülés (Rechnitzer, Lados 2004).

Témám, illetve az állam és annak különféle szervei szempontjából ez a tény azért jelentős, mert látszólag a globalizációnak ellentmondóan a gazdasági szervezetek egymásrautaltsága felerősödött, ami a vállalatok közötti együttműködés mellett a különböző helyi intézményekkel való szoros kapcsolatok kiépitésének a szükségességét is elismeri (közigazgatási, oktató, képző, fejlesztő stb. intézmények). Ez az állami szerepvállalás oldaláról is értelmezhető, azaz az állam a szabályozás, az ösztönzés és pénzügyi támogatás stb. eszközeivel helyzetbe tudja hozni az agglomeráció közigazgatási szereplőit, amelyek ily módon hozzá tudnak járulni a konkrét agglomeráció, illetve az abban földrajzilag koncentrálódó klaszterek versenyképességéhez (Lengyel, Rechnitzer 2004). Az unió tagállamainak város-, illetve agglomerációs politikájában a városrégiók rendre saját teljesítőképességük és versenyképességük kulcsaiként fogalmazódnak meg, kifejezetten stratégiai jelentőségüvé váltak.

Előre kell bocsátani, hogy elemzésem tárgyát a városrégiók kormányzása adja. Nem célom tehát a világvárosok hierarchiájának legfelső ranghelyein elhelyezkedő globális városok, a földrész-jelentőségű nemzetközi nagyvárosok, 
továbbá a több földrészre kisugárzó világvárosok szuperstruktúráinak vizsgálata (Erdősi 2003). A városrégió általános fogalmát igyekszem használni a továbbiakban, amely egy funkcionális teret fog át, amelyben az egy vagy több városmagot övező térségben az urbanizáció hatására agglomerálódási és szuburbanizációs folyamatok zajlanak. A városrégió alapját az agglomerációk képezik, amelyeket a népesség, a gazdasági tevékenységek, az infrastruktúra, a szolgáltatási-kereskedelmi kapcsolatok stb. nagyfokú területi centralizációja és koncentrációja jellemez. Az agglomerációk és agglomerálódó térségek lehatárolása és kategorizálása értelemszerűen országonként elfogadott eltérő metodika mentén történik, legfőképpen ebből a célból kiválasztott statisztikai adatok összessége segítségével (például lakóterület, minimális lakosságszám, népességnövekedés, népsűrűség, a munkahelyek száma, az ingázók aránya, a területhasználat intenzitása, a közlekedési elérhetőség, a jövedelmek képződése). Így az agglomeráció fogalma mást jelent Franciaországban, Németországban, Svájcban, és mást Magyarországon. Az agglomerációk formájában területileg összefüggő településrendszer jön létre, amely az épített környezet fizikai összenövésében is kifejeződik. Negatív megközelítésben a vidék elvárosiasítása egybefüggo „településmasszát” eredményez. E szerves téregységekhez azután az állam funkciókat, intézményeket, policyket rendel hozzá (vagy sem) saját érdekeitől vezérelve, attól függően, hogy milyen mértékủ befolyást kíván gyakorolni fejlődésükre, és mennyire akarja őket saját céljai megvalósításának szolgálatába állítani. A gazdaság a maga számára szintén értelmezi és többnyire előnyben részesíti e sürüsödési területeket, viszont a piaci szereplők a városrégiókat mint komplex tereket és eltérő „funkciócsomagokat” felkínáló intézményeket teszik mérlegre, aminek meghatározó eleme, hogy a különféle kormányzatok (beleértve a nemzeti, regionális és lokális szintet) miként pozicionálják azokat a nemzetközi és nemzeti városversenyben. Következésképp, mivel a városrégió területén elhelyezkedő helyi és területi kormányzatok adminisztratív határai eltérnek a funkcionális határoktól, a népesség és a gazdaság természetes mozgáspályáitól, konfliktus és versenyhelyzet keletkezik közöttük. Áthidalására, feloldására a legalkalmasabb eszköz az együttműködés, ami közösen definiált célok szolgálatában hosszabb vagy rövidebb távon létrehozza a városrégió egységét.

Szándékoltan nem szűkítem a vizsgálódást a metropoliszrégiókra, metropolisztérségekre, amelyek felfogásom szerint a városhálózat elemeiből a csúcskategóriát jelentik. Ezek ugyanis azok a nagyvárosi agglomerációk, amelyek az európai jelentőségű nagy központok hálózatát alkotják, és azt a léptéket testesítik meg, amivel a kisebb, policentrikus városrégiók csak együttműködések révén, a kritikus tömeg elérésével tudnak versenyezni. Ily módon a városrégió fogalmába a metropoliszrégiók is beletartoznak. Egyébként európai szinten a metropoliszrégióknak létesült egy exkluzív társulása, amelyet a METREX-program fog össze (Sinz 2005). ${ }^{2}$ Hozzá kell tenni, hogy fi- 
gyelmem középpontjában az európai kontinens, illetve az EU politikája által befolyásolt tér áll, amelyben a hazai agglomerációk esetleges intézményesülése számára irányadó folyamatokat veszem számba.

A vázolt keretek között dióhéjban megkísérlem végigkövetni a nagyvárosi terek intézményesítésére irányuló állami törekvéseket a 19. századtól napjainkig. Ennek során láthatóvá válik e téregységek céljában, funkciójában és a hozzájuk kapcsolódó állami szerepfelfogásban bekövetkezett folyamatos változás. E folyamat beleilleszkedik abba a tendenciába, amely a sokszintű kormányzás keretei között az államok térstruktúrájának átalakítására, területiségük újragondolására irányult leginkább a II. világháború befejezése óta. A városrégiók szervezeti formáit és azok módosulását egyelőre tendenciájában érintem, mivel a tanulmány az agglomerációk intézményesítésének kérdéskörére koncentráló OTKA-kutatási téma exponálására vállalkozik. A szervezeti formák részletes tárgyalása nyilvánvalóan további elemzéseket igényel.

A városrégiók intézményesítésének történetét a periódusok karakterisztikája alapján négy szakaszra tagolhatjuk:

1. a 19. század végétől a II. világháború lezárulásáig terjedő időszak;

2. az 1950-1970-es évek, az újjáépítés és a gazdasági fellendülés időszaka;

3. az 1970-es évek végétől az 1980-as évek végéig tartó szakasz;

4. az 1990-es évek elejétől napjainkig terjedő időszak.

Nem szorul magyarázatra egy olyan hipotézis, miszerint a modern urbanizációnak a nagyvárosokra gyakorolt hatása modellértékü szervezeti-intézményi struktúrákat rendszerint Nyugat-Európa országaiban generált, azonban nyilvánvalóan nem mondhatunk le a kronológiailag egy időben Magyarországot jellemző hasonló törekvések bemutatásáról. ${ }^{3}$ Már csak azért sem, mert a II. világháború utáni kelet-közép-európai urbanizáció elismerten (Enyedi 1992) nem hozott új modellt, hanem - bár megkésve - egyszerűen megismételte a korábbi nyugat-európai szakaszokat, legfeljebb sajátos vonásokkal egészítette ki azokat.

\section{A nagyváros-problematika mint igazgatási és tervezési kérdés megjelenésének elsố idő́szaka}

\section{A nagyvárosi igazgatás kezdetei Nyugat-Európában néhány példán keresztül}

A modern állam keretei között a nagyvárosi térségek szabályozástörténete a 19. század végére nyúlik vissza, s kisebb-nagyobb megszakításokkal máig tart. 
A nyugat-európai államok korán felismerték az agglomerációk fontosságát. A nagyvárosi igazgatás kérdésköre már az 1930-as években vizsgálat tárgyává vált, hiszen a világ nagyvárosainak speciális kormányzási igényére már jó ideje válaszok születtek. Ereky István (1936) jogi nézőpontból összegezte megállapításait, hogy törekvéssé vált Nyugat-Európában a külés gyárvárosok területét az anyaváros területébe bekebelezni, mi által a keletkező jogi kapcsolat az önkormányzatok területére és szervezetére egyaránt kihatással volt. A környező községek nagyvárosokba történt beolvasztása a 19. század városfejlesztő tényezőinek hatására igen gyakori volt, például a Német Birodalomban 1870 és 1910 között 93 város területét közel 170 ezer hektárral, népességét több mint tizenegymillió fővel növelték meg.

A nagyvárosi igazgatás bevezetésének első pregnáns példáit London, Berlin és New York szolgáltatta. Figyelemre méltó, hogy a közös tervezés, a területhasználat összehangolt szabályozása milyen gyorsan reális igényként merült fel a nagyobb városok és vonzáskörzetük községei viszonylatában. Nagy-Berlin (Groß-Berlin) már 1911-ben önálló szervezetet kapott célszövetség formájában. Az intézményesítés terén nagy karriert befutott Stuttgarti régió központi városa és a tőle húsz km-es körzetben elhelyezkedő önkormányzatok 1931-ben körzeti tervezési szövetséget létesítettek (Bezirksplanungsverband) az agglomerációra készítendő közös területi tervek és a településtervezés koordinációja céljával. 1937-ben emelkedett törvényerőre a Nagy-Hamburgot létrehozó törvény (Groß-Hamburg-Gesetz), amely a városközpont és a környező községek összevonásával úgynevezett egységes községbe (Einheitsgemeinde) fogta össze a teljes agglomerációt. A radikális megoldást városrészi dekoncentrációval enyhítették abban az időben (Stern, Püttner 1968, Somlyódyné Pfeil 2003a).

\section{Magyar elképzelések a városi térségek egységéról}

Hazánkban ez idő tájt a városok, illetve érdekképviseleti szervük, a Magyar Városok Országos Szövetsége sziszifuszi küzdelmet folytatott a kormányzattal a városok tervszerű fejlesztése érdekében. A szövetség 1928. évi kongresszusán már javasolta, hogy a város fejlődési környezetébe eső községeket igazgatásilag csatolják a városhoz, s azok indokolt esetben önállóságuk teljes feladásával is egyesülhessenek a várossal. Akkoriban városainkban még egyáltalán nem folyt sem rendezési, sem fejlesztési tervezési tevékenység, ezért az érdekszervezet kezdeményezte az erre vonatkozó kötelezés elfogadását. Azt is kérelmezte, hogy a kormány készítsen a városokra és községekre vonatkozó, országosan egységes építésügyi szabályzatot (Hencz 1973).

Egyes vidéki városaink részéről is megjelent az igazgatási terjeszkedés gondolata, ami a nagyvárossá alakulás feltételeinek megteremtését célozta 
az 1920-as és 30-as évtized fordulóján. Nagy-Pécs, Nagy-Győr, Nagy-Miskolc és Nagy-Szeged megszületése - elsősorban a szomszédos községek bekebelezésével - az adott térség ipari, kereskedelmi vagy éppen kulturális centrumát hozta volna létre. A nagyszabású tervekhez egy esetben járult hozzá a belügyminiszter - Hejőcsabának és Diósgyőrnek Miskolchoz csatolásával -, azonban a megye fennhatósága alá tartozó községek átengedésének a vármegye útját állta, az egyesülés csak a II. világháború után valósult meg. A törekvések kritikájaként megfogalmazódott, hogy az urbanizálódás szemszögéből még korai elképzelésekről volt szó, továbbá megvalósításuk tervszerüséget igényelt volna. Végső soron a kormány passzív szemlélője volt a sokszor igen korszerü elképzeléseknek és a városokat is elérő válságnak.

Hasonló sorsra jutott Budapest, noha Harrer Ferenc érdemeként 1908ban elkészült Budapest és a környező „társadalmilag összefüggő községek” egyesítésének terve. Harrer már akkor európai felfogásban vázolta fel az agglomerációigazgatás elveit. A városi vonzáskörzetek intézményesítésére vonatkozó koncepciókból a két világháború közötti időszakban nem volt hiány Magyarországon, legfeljebb azok nem jutottak el a megvalósításig. Ki kell emelni Mendöl Tibor, Erdei Ferenc és Magyary Zoltán nevét, akik javaslataikkal kiemelkedőt és maradandót alkottak (Somlyódyné Pfeil 2003).

Nagy-Budapest kialakításának tervét a KSH 1930-ban újfent elkészítette. A főváros területét az 1930:18. tc. megállapította, de az uralkodó osztályok nem engedték, hogy a munkáslakta városok és községek (például Pestszenterzsébet, Újpest, Kispest) a fővároshoz kerüljenek. Nagy-Budapest 23 környező város és község közigazgatási egyesítésével (az agglomeráció belső gyűrüjének bekebelezésével) 1950. január 1-jével jött létre. Viszont megemlíthető, hogy Budapest törvényhatóság volt, különleges jogállással, amelynek szervezetében fontos helyet foglalt el a Fővárosi Közmunkák Tanácsa. E szerv a városrendezés kérdéseiben nemcsak a fóvárosra, de a környékére is kiterjedő másodfokú építéshatósági jogot gyakorolt, miután 1937-ben sikerült elfogadni a városrendezésről és építésügyről szóló törvényt (Hencz 1973).

A városi vonzáskörzetek egységes igazgatására irányuló javaslatok rendre elvéreztek, aminek számos oka volt: a félfeudális társadalmi berendezkedés, a városhálózat urbanizáltságának alacsony foka, a közigazgatásnak a hatósági eljárásra koncentráló hagyományos jellege, a modern kommunális szolgáltatások megjelenésének nagyfokú késedelme Nyugat-Európához képest stb. Azt mondhatnánk, hogy az elméleti megoldások lépést tartottak a nemzetközi tendenciákkal, azonban az alapul szolgáló társadalmi-gazdasági folyamatok lényegesen fejletlenebbek voltak. 


\section{Az agglomeráció-igazgatás a jóléti állam modelljének keretei között - a területi reformoktól a közigazgatási városrégiókig}

A II. világháborút követő időszakban, az újjáépítés lendületében számos fejlett nyugat-európai állam felülvizsgálta történelmileg kialakult lokális önkormányzati rendszerét, és azzal összefüggésben átalakította területi struktúráját. Tette ezt a gyors urbanizáció, a gazdaságban és a társadalomban bekövetkezett mélyreható változások hatására, amelyek az államról és a közigazgatás rendeltetéséről vallott felfogást is módosították. Meggyökeresedett a jóléti állam eszméje, a hagyományos rendészeti jellegü és szűk körű kompetenciát birtokló közigazgatást pedig felváltotta a közszolgáltatásokat nyújtó közigazgatás képe. A növekvő igényekre az államszervezet és térszerkezet korszerüsítésével lehetett megfelelő válaszokat adni. Széles körben vizsgálták az önkormányzatok legkisebb méretének kérdését a feladatellátás hatékonyságának és a méretgazdaságosságnak a szemszögéből. A mérethatékonyság megvalósítására számos államban radikális községösszevonásokat hajtottak végre az úgynevezett nagyméretű, az elemi településektől elváló mesterséges önkormányzati alapszint létrehozására. A községhatárok racionalizálásának módszerét alkalmazta Svédország, Dánia, Norvégia, Nagy-Britannia, több német és osztrák tartomány, majd a későbbiekben Hollandia és Belgium is.

A kevés nagyméretű önkormányzatra történt áttérés egy vagy esetleg két hullámban egyesítette a municípiumokat, előbb az önkéntesség, majd annak eredménytelensége után a kötelezés eszközével. A területszervezés alapelve a skandináv országokban a városok és szűkebb környéküket alkotó községek egyesítése volt. Egy második hullámban már a távolabbi községegyütteseknek a városokba való bekebelezése valósult meg. A reform eredményeként létrejött önkormányzati alapszint előbb bizonyos körzeti jellegü alapszolgáltatások méretbeli igényeinek felelt meg, majd pedig - például Svédországban - a középfokú oktatás és a városkörnyéki tervezés igényeit elégítette ki (Europarat 1976, Verebélyi 1993). A város és vidék közötti különbségek áthidalásának szándéka állt a kettő egyesítésének reformgondolata mögött Hollandiában és Belgiumban. A cél nem utolsósorban az volt, hogy az állampolgárok számára garantálják az azonos értékű és minőségű közszolgáltatásokhoz való hozzáférést, aminek módszere az alkalmas központi szerepkörű önkormányzatok kialakítása volt.

A folyamat átfogó terïleti reformként vonult be a közigazgatás-történetbe, és tagadhatatlanul funkcionális reform is kapcsolódott hozzá. A területi reform égisze alatt strukturális értelemben újraszabályozták a központi állam, a területi szint és a lokális önkormányzati egységek viszonyát, majd az előbbihez kapcsolódóan funkcionális értelemben újraosztották a feladatokat és kompetenciákat. A funkcionális átalakítás - Nagy-Britannia kivételével - általánosan 
decentralizációban öltött testet, a kapacitásában is megnövekedett alapszint alkalmassá vált a területi típusú feladatok, valamint a korábban állami ügyek fogadására. A funkcionális reform magját az önkormányzatok finanszírozásának megreformálása jelentette (Zehetner 1982).

Németországban, ahol tartományonként eltérő intenzitással valósították meg a térstruktúra átalakítását, Észak-Rajna-Vesztfália tartományban a reformnak három célterülete és egyúttal területi léptéke volt (Gründler 1974):

- először a vidéki térségek önkormányzatait alakították át;

- azután az agglomerációkban hajtották végre a város- és községegyesítéseket, továbbá a járások területi léptékét változtatták meg;

- végül megtörtént a tartomány állami és regionális átszervezése.

A területi reform végigvitele önmagában nem oldotta meg a nagyvárosi kormányzás problémáját, eszközszerepében csupán egy lépcsőfokot alkotott az intézményesítéshez vezető nehéz úton. Jól jellemzi ezt az a történet, ahogy Alsó-Szászország tartomány egyetlen agglomerációja Hannoveri régióvá fejlődött. A nagyvárosi térség első társulási alkotmányát 1962-ben mindenekelőtt a közös tervezés igényétől vezérelve bocsátották ki. A szervezetfejlesztést megalapozó anyagok már négy évtizeddel ezelőtt hangsúlyozták, hogy a városkörnyékek legfontosabb jelensége a gazdasági és társadalmi összefonódottság. Ennek adminisztratív kezelése során rámutattak arra, hogy e térben a „regionálipatriotizmus” előtérbe kerül a lokálpatriotizmussal szemben. Tehát az 1960-as években nem egyszerüen közigazgatási reformról, hanem a sokoldalú „városrégió” kérdéséről folyt a gondolkodás.

Hannover esetében az első rangú elv az optimális szolgáltatóképesség kialakítása volt, összefüggésben a közigazgatás egységének és egységes felépítésének elvével. A vonzáskörzet községeinek városmagba való beolvasztása helyett az 1974-ben lezajlott reform során a vonzáskörzetet egységben értelmezték, és a területén lévő kisközségeket vonták össze. Ezzel megszülettek a szolgáltatásszervezés szempontjából optimális (minimálisan 7-8 ezer lakosú) önkormányzati egységek. A döntés célja az agglomerációban a „központi helyek" kialakítása, ezáltal a városmag és a városkörnyék szükségtelen szolgáltatási összefonódásának kiküszöbölése volt. Az intenzív területrendezés nemcsak azért tanulságos, mert Hannover városát részben tehermentesítette, hanem azért is, mert létrehozta az agglomeráció területén azt az ésszerü számú községet, amelyek az együttmüködésben a nagyváros partnereivé tudtak válni. A városkörnyék közigazgatási erejének növelése eltüntette az önkormányzatok nagyvárosba való bekebelezésének igényét. A nagyváros kormányzását egy speciális társulási modell (Verband Großraum Hannover) kiépítésével oldották meg, amely az állam szempontjából fontos tervezési és pénzügyi kiegyenlítési kompetenciák fogadására is képessé vált (Stern, Püttner 1968).

Nagy-Britannia 1974-ben maga is átfogó reformot vitt végig, amely az agglomerációk intézményesítését is magában foglalta. A korábbi négyszereplős kommunális önkormányzat helyén egy új, kétszintü struktúrát vezetett be, a 
továbbiakban az „county”-k (megyék) és a „district”-ek (járások) között osztotta meg az önkormányzati feladatokat. Az ettől való eltérést az úgynevezett metropolitan county borough-knak az agglomerációk területén történt intézményesítése képezte. Angliában hat nagyvárosi county (Greater Manchester, Merseyside, South Yorks, Tyne \& Wear, West Midlands, West Yorks) és 36 nagyvárosi district jött létre. Az általános eredményt tekintve koncentrált és racionalizált, végső soron egyszerüsített önkormányzati rendszerről lehetett beszélni, amelynek alapszintje a járás, második szintje a megye lett. A kritikák vitatták, hogy a kialakult rendszer hatékony lett volna, és az önkormányzatok demokratizmusát erősítette volna, inkább a belső szervezeti modernizációt szokták eredményeként elismerni, minthogy a nagy téregységek lehetővé tették új menedzsmentmódszerek alkalmazását, az egységes és egyeztetett önkormányzati fejlesztési tervezést és a hatékony pénzügyi ellenőrzést. Végső soron a központi ellenőrzés s rajta keresztül az állami irányítás centralizáltsága erősödött.

Az 1950-1970-es években a nagyvárosi politikai intézmények széles körű bevezetése valósult meg Nyugat-Európában. Az agglomerációigazgatást jellemző szervezeti burjánzás kiindulópontja az a gazdasági szükségszerüség volt, hogy a városrégiót egy globális igazgatási egység fogja át. ${ }^{4} \mathrm{~A}$ nagyvárosi kormányzati szervezetek valós gazdasági hatalma nagyobb volt, mint amekkora a jogi szabályozásból következett volna. Az európai államokra ezért is jellemző, hogy valamilyen módon a kezdetektől részt vettek a városrégiók intézményesítésében vagy működtetésében, esetleg mindkettőben (Balázs 1988).

E szervezeteknek megállapíthatók voltak közös jellemzőik:

- Céljuk: az állam modernizációja.

- Irányultságuk: az igazgatási hatékonyság megteremtése, helyi közszolgáltatások mérethatékonysági szempontú optimalizálása, az agglomeráció léptékében értelmezett egységes területi tervezésnek és az agglomeráció egészén belüli pénzügyi, illetve adókiegyenlítésnek a megvalósítása.

- Szervezeti karakterük: bürokratikus. Egyrészt az együttműködést intézményesítő szervezetek célja az volt, hogy áthidalják azt az ellentmondást, amely az agglomerációk mint funkcionális területi egységek és a területükön fekvő közigazgatási egységek határainak eltéréséből fakadt. (A megoldás többnyire igazgatási karakterű szervezetek alapítása volt.) Másrészt a létrehozott közigazgatási egységek a fordista tömegtermelés analógiáján alapultak, gyakran külön szakapparátust müködtettek (esetenként több száz fős hivatallal müködő szervezetek voltak).

- Közös elméleti hátterüket a keynesi jóléti nemzetállam modellje adta. Abban elsőbbsége volt a nemzeti léptéknek, az állam szabályozó hatalma révén támogatta a nemzeti gazdaság fejlődését mindenekelőtt infrastrukturális beruházásokkal, és segítette a városi agglomerációk fizikai expanzióját is. 
Az agglomerációigazgatásnak mindig is érzékeny pontja volt a finanszírozás, mivel az agglomeráció politikai fragmentáltságának kezelése mellett ez a másik alapkérdés, ami állami beavatkozást igényel. A második fejlődési szakaszban az európai államok pénzügyi eszközökkel intenzíven ösztönözték a városrégiók közös kormányzási szerveinek létesítését és müködését. A nagyszervezetek speciális állami szubvenciókat kaptak, egyes országok (a német és francia rendszerben) helyi adók, illetve adójellegű kötelezettségek kivetésére, valamint önkormányzati hozzájárulások beszedésére jogosították fel őket. Szerepük azonban ennél is tovább ment, részt vettek a területükön lévő helyhatóságokat megillető állami támogatások elosztásában, ami folytonos küzdelemre késztette az agglomerációs önkormányzatokat. ${ }^{5}$

Nem véletlen, hogy a területi reformok szerves részét alkotta az önkormányzati finanszírozási reform. Itt a legtágabb értelemben fiskális föderalizmusról beszélhetünk, amelybe az önkormányzatok közötti horizontális verseny és a kormányzattal való vertikális kapcsolatrendszer beleilleszkedik. A pénzügyi föderalizmus hivatott kezelni a szabályozáspolitikai, a döntési, szolgáltatásszervezési és területpolitikai szempontrendszert egyaránt. A közösségi jólét költségeit és hasznait az állam a maga eszközeivel segít optimalizálni (Horváth 2008). Tehát a finanszírozás rendkívül összetett problematika. Magában foglalja a városrégió önkormányzatai közötti pénzügyi kiegyenlítés metodológiáját, az együttműködésnek mint szervezetnek a fenntartását, a tervkészítés finanszírozását, majd a tervek implementációját, a városrégióknak mint fejlesztési tereknek a támogatását, továbbá speciális eszközként számos országban a tervszerződések rendszerét, amely kontraktusokat a kormányok a városokkal kötnek meg (Tosics 2008, Horváth 2011). Mindennek magyarázata, hogy az agglomerációk jövedelemelosztási kérdésként vetődnek fel az állam számára, aminek megválaszolásában minden korszakban szerepet kell vállalnia.

Tehát a városrégiók intézményesítése mint a kapitalista urbanizáció kezelési stratégiája jelent meg a vizsgált időszakban, aminek során az állam szabályozó hatalma különféle területi konfigurációkat létesített (Brenner 2003). Ezek leginkább az agglomerációk funkcióképésségének garantálását célozták. Azt is hozzátehetem, hogy az agglomerációkra alapított szervezeti megoldások általában kivételes intézményesítési formában öltöttek testet, amelyek a megoldandó feladatok különbözőségének és a sokszínü adottságoknak köszönhetően az állam általános közigazgatási tagolódásától és szervezeti struktúrájától gyakorta elkülönültek. A gondolatsort megfordítva megállapítható, hogy nem jött létre stabil, időtől független közigazgatási minta, kifejezetten és kizárólag a nagyvárosi térségekre alkalmazható szervezeti modell, amely végérvényes megoldást hozott volna az intézményesítésre. Ez alól időszakosan voltak és vannak kivételek, amikor egy-egy ország több agglomerációjára egységes szabályozási keretet hozott létre (például a volt francia városközösségek, az olasz citta metropolitana, az angol Metropolitan County Council). Ez a szervezeti 
változékonyság és változatosság legfőképpen azzal magyarázható, hogy a nagyvárosi térségek együttműködési és koordinációs igényét a gazdaság fejlődésének dinamikája határozza meg. A kérdésekre adandó válaszok mind kevésbé köthetoók merev közigazgatási határokhoz, sokkal inkább a közigazgatás teljesítménye és a tervezés hatékonyságának növelése adja a lényegüket. Ezért is kapcsolódik össze a városi kormányzás problematikája a regionális fejlesztéspolitikával.

A városi kormányzásban e második fejlődési periódus az intézményesítés felfelé ívelő időszakasza volt. Ezért bőséges lehetőséget kínált az agglomerációigazgatási szervek tipizálására, amit szerzők sora végzett el itthon és külföldön. ${ }^{6}$ Abban az időben a központi államok rendszeresen megpróbálkoztak azzal, hogy ezeket az intézményeket az állam általános területbeosztásába, illetve közigazgatási egységei közé illesszék. Végül ezek a megoldások maradtak kisebbségben, tekintve, hogy az alapul szolgáló agglomerációk leginkább funkcionális téregységek voltak, amelyeknek határai természetes módon átmetszették az adminisztratív térfelosztásokat. Tehát erre a problematikára a kézenfekvő gyógyírt a környező önkormányzatoknak a városmagba való beolvasztása (mai elnevezéssel konszolidációja) szolgáltatta, ami a helyhatóság növekvő ellenállásába ütközött, ezért fokozatosan elveszítette „szalonképességét”. Emellett akadtak szép számban olyan koncepcionális megközelítések, amelyek a városrégiókban a közigazgatási struktúra egyszerüsítését, igazgatási szintek kiiktatását, továbbá a létrehozandó új típusú agglomerációs szervvel az önkormányzati és állami feladatok hatékonyabb és célszerübb újratelepítését célozták. A városrégió léptékében tehát speciális, az állam általános közigazgatási felépítésétől eltérő adminisztratív egység született. E törekvés kiemelkedő példája a német politikai gondolkodást évtizedeken keresztül foglalkoztató úgynevezett regionális járás modellje, amely több mint három évtizedes előkészítő munka után realizálódott. A már említett Hannoveri régió az önkormányzatok horizontális kooperációjából nőtte ki magát. A lokális és a központi akaratra egyaránt szükség volt a regionális járás létrehozásához, amit végül 1999-ben a tartományi törvényhozás szentesített (Somlyódyné Pfeil 2005).

\section{Az agglomerációigazgatás a fordista-keynesi típusú állam válságának periódusában}

A kései 1970-es években és az 1980-as évek elején gyökeres fordulat következett be, mivel az előzó évtizedben kiépült nagy technokrata szervezetek hitelüket vesztették. Okai között találjuk, hogy a fordista-keynesiánus fejlesztési modell válságba került, következésképp az újraelosztó regionális politikai modellt felváltotta az endogén forrásokra építkező gazdaságfej- 
lesztési modell. Belső problémák is nehezíteni kezdték a nagyvárosi igazgatást, lévén általában „fentről” kezdeményezett szervezetek voltak, pusztán funkcionális céloknak alárendeltek, s többségüknél felmerült a lokális legitimáció hiánya. Tekintettel arra, hogy tervezési jogosítványaik révén erőteljesen beavatkoztak a területileg érintett önkormányzatok autonómiájába, tervezési agendájukat más területi szervezetek támadták. Mindennek következménye számos nagyvárosi igazgatási szervezet felbomlása, végső esetben a központi állam általi feloszlatása lett. Az Egyesült Királyságban, Hollandiában, Dániában és Spanyolországban az 1980-as évek során különféle okoknál fogva (politikai események, a sikeresség hiánya, a feladatok és felelősségi viszonyok zavara stb.) az agglomerációs igazgatási szervezetek megszűntek. E nagyméretű bürokratizált szervezetekre - úgy tűnt - egy időre nincs szükség. Ez alól pozitív kivételként említhető Franciaország, ahol a városi közösségek mint regionális testületek kontinuitása meg tudott maradni.

Ebben a harmadik fejlődési szakaszban a politikai környezet megváltozott, liberalizálódott és nagymértékben leépült a hagyományos jóléti politika. ${ }^{7}$ A globalizációhoz való alkalmazkodás jegyében a nemzetállamoknak ahhoz füződött érdeke, hogy a gazdasági kapacitásokat és az infrastrukturális beruházásokat ismételten koncentrálják, a versenyképes városokba és ipari körzetekbe való telepítésüket támogassák. Megmutatkoztak a válság jelei a területi egyenlőtlenségek növekedésében is, mivel a lokalitások közötti verseny (a zéró végösszegü játszmák sora) aláásta az adott ország versenyképességét. Ennek fó oka az volt, hogy helyi gazdaságfejlesztési stratégiák müködtek, amelyek között nem volt területi szintü koordináció, következésképp az alapul szolgáló politikai széttöredezettség ellensúlyozásához új megközelítésre volt szükség, ami elvezetett a regionális léptékủ gondolkodáshoz és cselekvéshez.

A vizsgált korábbi két fejlődési periódusban a nagyvárosi kormányzást hagyományosan a közigazgatás szférájában lehetett értelmezni. Ebben az átmenetinek is nevezhető szakaszban a válságkezelés következményeként magának a közigazgatásnak a mozgástere is kitágult. Ezért mondhatjuk azt, hogy a változások másik meghatározó jegye a közigazgatás nyitottságának növekedésében ragadható meg, mivel a hagyományosan hierarchikusan, zártan szerveződő szektor mindinkább interaktív kapcsolatokat alakított ki saját rendszerkeretein belül éppúgy, mint a gazdasági és civil szektor irányában (Horváth 2002). Ez a szimptóma pedig nem választható el a New Public Management névvel illetett reformoktól. A jóléti államrendszer megingásának következményeként Európán végigfutott reformok hatásaként egyrészt az igazgatásszervezésbe benyomultak a magángazdaság módszerei és a privatizáció, másrészt a kormányzásban megfigyelhető a helyi-területi hatalomgyakorlás színtereinek pluralizálódása. 


\section{Az urbanizáció hatása a városigazgatásra a szocialista Magyarországon}

Magyarországon a szocialista területpolitikát a településhálózat-fejlesztés szempontjából mint a városokra irányuló politikát minősíthetjük, amely több tekintetben koncentrációs folyamatokat idézett elő. Budapest szerepe mindvégig kitüntetett volt, s az időszak eredményeként tagadhatatlanul megteremtődött Magyarország modern városhálózata, megerősödött középváros-hálózata, és bővült a kisvároshálózat. Az életkörülményekben meglévő különbségek az egyes településkategóriákon belül csökkentek, azok között viszont növekedtek.

Ami a várostérségi kapcsolatok intézményesítését illeti, nem volt összhang az igazgatási rendszer korszerüsítése és a településhálózat-fejlesztés között. Az Országos településhálózat-fejlesztési koncepciónak és a területfejlesztés irányelveinek kibocsátásával egyidejüleg, ${ }^{8}$ 1971-ben indult el a kétszintű igazgatási rendszerre való áttérés, amely a járások fokozatos kiiktatása mellett a várostérségi érdek lassú elismeréséhez vezetett (Szoboszlai, Wiener 1978). A folyamat végkifejleteként 1984-ben a területet lefedő módón és egységes szervezeti modellt követve bevezettük az úgynevezett városkörnyéki igazgatási rendszert. A modell nem volt tekintettel sem a városok hierarchiaszintjére, sem a várostérségi kapcsolatok intenzitására. Egy döntő részben igazgatási városkörnyék létesült, amely egyfelől a központváros és a városkörnyékhez kijelölt községek között igazgatási hatósági jellegű, másfelől a városi tanácsok által a községi tanácsok felett gyakorolt felügyeleti jog következtében felügyeleti típusú hierarchiát hozott létre a kívánatos mellérendeltség és egyenjogúság helyett. A szervezeti probléma úgy summázható (Kilényi 1985), hogy a városkörnyéki községeknek nem volt képviseletük a központi város tanácsában, míg a városi szerveknek nem volt hatáskörük a városkörnyékre nézve.

Nem tudott kikristályosodni speciális intézményi keret a fóváros és az agglomerációk, településegyüttesek együttműködésére. Elsőként a budapesti agglomeráció jelent meg a statisztikákban, miután a kormány 1971-ben elfogadta Budapest föváros és környéke általános rendezési tervét, amely gyakorlatilag az OTK-val egyidőben 44 településben határozta meg az agglomeráció kiterjedését. Bár 1985-től folyamatossá vált az agglomerációkra, településegyüttesekre és városcsoportokra vonatkozó adatgyüjtés, a kapcsolatok formalizálása nélkül a célkitűzések papíron maradtak. ${ }^{9}$

A területfejlesztés irányelvei 1971-ben megállapították, hogy Budapest és környéke viszonylag túlfejlődött, ezért ki kell dolgozni a körzet fejlesztéspolitikai koncepcióját. A foglalkoztatás és az ipar kérdései mellett a korabeli dokumentum azt is kimondta, hogy a budapesti agglomerációban társadalmi-gazdasági feszültségek alakultak ki, amelyek a települések ellá- 
tottsági színvonalában lévő különbségekben öltöttek testet, így gondoskodni kell azok feloldásáról és az egész terület összehangolt fejlesztéséről. Az OTK mindezt azzal egészítette ki, hogy a koncepció 9. pontjában az agglomeráció központja és a hozzá tartozó települések összehangolt fejlesztését tűzte célul. A budapesti agglomerációs gyürü fontosságának elismerését mutatta, hogy az említett koncepcióban az érintett városok és községek önálló központi szerepköri besorolást kaptak (I., II., III.), s nem tagolódtak be a középfokú központok rendszerébe (Kilényi 1985). E feladatmeghatározások azonban nem vezettek a nagyvárosi térségek kiemelt kezeléséhez, sem a budapesti, sem a miskolci agglomeráció, sem további agglomerálódó térségek közigazgatási intézményesítéséről nem született döntés.

$\mathrm{Az}$ állam adekvát válasza elmaradt, ami Budapest esetében részben érthető volt, mivel Nagy-Budapest kialakításáról az a vélemény alakult ki, hogy a 23 környéki településnek a fóvárosba történt bekebelezése az agglomeráció számottevő részének a város közigazgatási határain belülre kerülését eredményezte, így a szuburbanizáció hosszabb időn keresztül részben a városon belülre irányult (Perger 1999). Másfelől a városkörnyékek kialakítása leghátrányosabban talán Budapestet érintette. Igaz ugyan, hogy az agglomerálódás általánosan elfogadott ismérveinek mindegyike csak a fővároshoz közelebb fekvő községekben alakult ki, viszont a Budapesttől elszakított módon bevezetett városkörnyékek kohéziója alacsony volt. A városkörnyéki kapcsolatok léteztek, de nem az igazgatási központok felé irányultak, hanem a fơvárosba vezető közlekedési útvonalak mentén füzték fel a településeket (Beluszky 1987).

Ezzel szemben a területi tudományok már meglehetősen korán felismerték a problematika fontosságát, ugyanis 1973-ban az MTA Dunántúli Tudományos Intézetében megkezdődött a budapesti agglomeráción kívüli agglomerációk és agglomerálódó térségek komplex szemléletű kutatása (Csefkó, Rechnitzer 1979, Rechnitzer 1985). A folyamatokat összegezve Kőszegfalvi György úgy fogalmazott, hogy a településrendszer strukturális változásának egyik meghatározó vonása az ország egyes térségeiben végbemenő agglomerálódási folyamat, továbbá az agglomerációk létrejötte (Kőszegfalvi 1985).

A megkésett urbanizáció ellenére érdemes a hazai folyamatokat a nyugat-európaiak tükrében nézni. Már csak azért is, mivel a tanácsigazgatás keretei között kialakított közös tanácsok rendszere - bár nem merítette ki a községösszevonások fogalmát, és nem hozott területi reformot - egyes céljaiban és eredményeiben a fejlett országokban tapasztaltakhoz hasonlított. Az integrált alapszintủ tanácsi szervek létrehozásának és az államigazgatás színvonalának, hatékonyságának növekedésében rejlő előnyöket a városkörnyéki modellben nem sikerült kiaknázni. 


\section{A nagyvárosi kormányzás reneszánsza, avagy a városrégiók a posztfordizmus keretei között}

Az 1990-es évtizedtől a figyelem ismételten az agglomerációk felé fordult, amit már érdemes a globalizációba ágyazottan szemlélni. A globális gazdaságban elengedhetetlen a regionális léptékủ cselekvés, a versenyképes városi térség léptéke pedig a városrégió, illetve a vele egyenrangú szereplőként fellépő városhálózat lett. A szakemberek a városok regionalizálódásának nevezik azt a folyamatot, amelynek során a városi vonzáskörzeteket is elérte a decentralizáció, a várost és térségét többé már nem centrum és periféria ellentmondásaként értelmezik, mert egységet kell alkotniuk egymással. A városi térségeket új fogalmakkal jelölik: regionális város, közbenső város, hálózatváros vagy peremváros. A regionalizálódást nem csupán fizikai-materiális valóságként kell felfognunk, mert a régió az emberi tevékenység kimenetét is jelenti, amely a társadalmi kommunikációba beleszövődik (Kühn 2001, Varró 2010).

A nagyvárosi kormányzás újabb hullámának fókuszában a gazdasági prioritások állnak (olyanok, mint a területi versenyképesség és a külső tőkevonzási képesség) a gazdaságföldrajzi és uniós integráció kontextusában. Az átalakulások nagyságrendjét mi sem bizonyítja jobban, mint hogy a városrégiók intézményi reformjának jelenkori formái abba a folyamatba illeszkednek, amelyben az államok térstruktúrájukat átalakították (rescaling). A lokális és a mezo szint felértékelődése (Pálné Kovács 2006, Józsa 2006) az 1990-es évektoll kezdődően - nem kevéssé a „régiók Európája” felfogás hatására - számos európai államban strukturális adminisztratív reformokat indukált, aminek köszönhetően decentralizációs tendenciák érvényesültek a különféle területi szintek javára. Ez legfőképp az újnak tekinthető regionalizált és a decentralizált unitárius államtípus megszületésében, továbbá a föderális államok körének bővülésében öltött testet. A területi hatalomgyakorlás e szerkezeti átrendezödésének jelentősége átlépte a közigazgatás-szervezés határait, és politológiai szempontból értelmeződik (Weck 1995).

Ez nem véletlen, mivel időközben lezajlott a posztfordista társadalmi formációba való átmenet. Ennek jellemzői gazdasági kontextusban a termelés és a munkaerőpiac „flexibilissé válása” és „nemzetköziesedése”, politikai-kulturális területen a kormányzási mechanizmusban a "dereguláció" végigvitele, területi-társadalmi dimenzióban a „polarizáció” felerősödése. E tényezők újfajta társadalmi fejlődési modellhez vezettek, amelyben a gazdaság átstrukturálódása és a területi hatalomgyakorlás új formáinak kialakulása szervesen összefonódott. A városrégiók fejlődési mintái leginkább azzal írhatók le, hogy a gazdasági és politikai szereplőknek egy folyamatosan változó és komplex mátrixban kell működniük. Már nem elegendő, hogy a vállalatok puszta törvényi előírásokat kövessenek, hanem a regionális-lokális szereplők által kialkudott struktúrák közepette kell működniük, ahol a konkrét szabályok 
tartalmát politikai-kulturális, helyi társadalmi struktúrák és hatalmi viszonyok befolyásolják (Weck 1995).

Az államok területiségében tetten érhető változások, urbánus-regionális dimenziójú újrastrukturálásuk a regionális léptékű gondolkodás megtestesítői a globalizáció szupraregionális égisze alatt. A városrégiók adják az egyik térbeli struktúrát, amelyben a társadalom nemzeti, regionális és lokális szereplői globális perspektívával kooperálni tudnak. Az is megállapítható, hogy az európai integráció maga is erősítette a területi versenyt, ezért Európa nagyvárosi térségeiben (Glasgow, Manchester, Randstad, Brüsszel, Hannover, a, Ruhr-vidék, Frankfurt, Stuttgart, München, Párizs, Lille, Lyon, Madrid, Barcelona, Bologna, Milánó) a kormányzás növekvő mértékben a gazdaságfejlesztési politika (policy) mechanizmusaként aktiválódott. A többi nagyvárosi térségre is igaz, hogy a városmag és a szuburbán gyürü között létrejött új együttmüködési keretek lényeges szerepet kapnak a területi fejlödés elösegítésében, ahhoz teremtik meg az intézményi előfeltételek bázisát (Brenner 2003).

Az idő előrehaladtával kétségbevonhatatlanná lett Fürstnek (1991) az a két évtizeddel ezelőtti állítása, hogy a nemzetközi munkamegosztás és hálózatosodás (ma globalizációnak neveznénk) erőteljesebbé válásával valamely ország gazdaságának fejlődése nagyvárosi térségeinek fejlődésétől függ. A városrégiókat a gazdaság működési logikája értékelte fel, így a várospolitika és az agglomerációs politika egyszerüen a gazdaságpolitika részévé válhat. A régiók közötti versenyben új együttmüködési formák termelődtek ki, amit public-private partnerségnek neveztek el, s amelynek gyökerei és hagyományai az USA-ban keresendők, majd Európában is megkezdték kipróbálását, az elsők között a Ruhr-vidéken az 1980-as évek végén.

A gazdasági és a közigazgatási változásokon túl a nagyvárosi kormányzás intézményesítésében tapasztalt korábbi kudarcok is hozzájárultak egy olyan kompromisszumos megoldáshoz, amely a kormányzási problémákat informális partnerségeken keresztül törekszik kezelni. Az ezredfordulón az úgynevezett „új regionalizmus” a nagyvárosi régiókat tekinti a gazdaságfejlesztés természetes tereinek, amelyekben a gazdaságot ösztönözni kell. Ennek az elméletnek aztán meghatározó befolyása lett a nyugat-európai városrégiókat jellemző úgynevezett „urban governance”, vagyis a városi kormányzás elméletére, gyakorlatára és intézményes formáira (Somlyódyné Pfeil 2008).

Ha az agglomerációban létrejött kooperációkat a szereplők oldaláról nézzük, azt látjuk, hogy a központi város és vonzáskörzete önkormányzatainak kooperációja egy sürü kapcsolatokkal átszőtt térben működik, amely horizontálisan és vertikálisan is értelmezhető, hiszen az együttműködést egyértelmüen két irányból érik hatások. Először is az úgynevezett kollektív javak, vagyis a közszolgáltatások (termékek) közös előállításából és fogyasztásából származó területi és funkcionális munkamegosztás, valamint a lehetőségek megtöbbszöröződéséhez és a költségcsökkentéshez füződő érdek (az infrastruktúra használatának optimalizálásából származó előny) ösztönzi a feleket kooperá- 
cióra. Másodszor beszélhetünk rendszerhatásokról, amelyek abból adódnak, hogy az önkormányzatok egy mind komplexebb és újabb vertikális függelmi viszonyokat létesítő kormányzási rendszerbe ágyazódnak bele, ami ugyancsak az együttműködés felé tolja őket (Fürst 1991).

Noha a regionalizációval összefüggésben szeretünk decentralizációról beszélni, a valóságban a centralizációs és decentralizációs folyamatok összekapcsolódnak. A regionális és helyi szereplők ugyanis a vertikális intézményi felépítménybe egyre erőteljesebben beépülnek, ami több okból fakad. Egyrészt a területi szereplők igyekeznek alulról befolyásolni a központi döntéseket, másrészt mind gyakrabban beleütköznek az állami szakpolitikákba, amelyek priorizálják az erőforrások és fejlesztések térbeli elosztását. Harmadszor, a gazdasági szereplők felettébb érdekeltek abban, hogy az állami és uniós forrásokért vívott küzdelemben az adott régió eredményes legyen. Ezek a tényezők egyaránt a vertikális kapcsolatokat erősítik, és a centralizáció irányába viszik a struktúrát. Közben a másik oldalon valóban kitapintható a decentralizációra való hajlandóság, az endogén erőforrások mobilizálása, a civil szervezetek és a társadalmi erőforrások bevonása a fejlesztéspolitikába. Sőt, a közszolgáltatások terén, az állami és önkormányzati teljesítmények nyújtásának módozataiban a privatizáció és az államtalanítás eszméje valósul meg. A kérdés tehát az, hogy a centralizációs és decentralizációs tendencia eredőjeként bekövetkezhet-e a feladatok és kompetenciák újraelosztása a különféle szintek között, vagy pusztán arról van szó, hogy a szubnacionális szintek egyre jobban „bevonódnak, beleszövődnek” a vertikálisan fölöttük megszületo” döntésekbe, s ily módon közvetett felelösségük keletkezik azokért. Ami korábban csak felsejlett, azt napjainkban vizsgálatok bizonyítják (Kuindersma, Boonstra 2010). Nemrégiben folyt egy olyan kutatás, amely a holland regionális partnerséget elemezte a rurális politika keretei között, aminek célja az állam szerepének meghatározása volt a partnerségi kormányzásban. Az állami-önkormányzati, gazdasági és civil szervezetek alkotta partnerségek fejlődésére vonatkozóan levont egyik érdekes tanulság éppen az volt, hogy azok az állami politikák végrehajtásának alkalmas eszközei, s az állam sok esetben saját céljainak érvényesítésére használja őket.

Az új kormányzás, a „governance” módszerének hatására a városrégiók intézményesítésének kérdése, csakúgy mint a régióké, differenciálódott. Ma már nincs arról szó, hogy a városrégiónak közigazgatási egységgé kellene válnia, illetve, hogy bele kellene tagolódnia a közigazgatási szervezetrendszerbe. Elegendő, ha önigazgatás alapján működő intézményesített cselekvési szintté válik. Hiszen az új kormányzás nem érinti a fennálló kormányzási struktúrát, hanem elsődlegesen annak folyamatával és funkciójával áll kapcsolatban, ezért eredményorientáltan közelíti meg a regionális természetű kérdéseket. $A$ nagyvárosi kormányzást mint a gazdaságfejlesztési politika mechanizmusát értelmezik a helyspecifikus társadalmi-gazdasági előnyök erősitése céljával. Egyidejüleg a lokális gazdaságfejlesztési stratégiák regionális szintű versenyképességi stra- 
tégiaként fogalmazódnak meg, átfogva a teljes városrégiókat. Megfigyelheto", hogy a nemzeti és helyi gazdaságpolitika egyre direktebb módon a városrégió léptékében kapcsolódik a területi tervezéshez, az infrastrukturális beruházásokhoz és a társadalmi-gazdasági koordinációhoz.

A nagyvárosi terek újrastrukturálásának folyamata nyilvánvalóan városrégiónként elemezheto", figyelembe véve a nemzeti és helyi szintű adottságokat, különösképpen az ipari-gazdasági környezetet, továbbá a közigazgatásialkotmányos rendszert. Ennek ellenére a folyamatnak, a városrégiók új típusú intézményesülésének, illetve kormányzásának megnevezhetők általános jellemvonásai, trendjei is (Brenner 2003, Herrschel, Newman, 2002, Keating 2001):

- Célja: hozzájárulás az adott állam és tágabban az Európai Unió gazdasági versenyképességéhez (versenyképességi regionalizmus), a régiókon belüli verseny csillapítása és a városrégiónak globális, szupranacionális és nemzeti szinten való pozicionálása. A nagyvárosi reformok a telephelyi politika formájaként öltöttek testet.

- Irányultsága: prioritásai középpontjában gazdasági célok vannak, a külső tőkevonzó képesség erősítése szerepel, erős a vállalkozói orientációja, amiben kifejeződik a globalizáció kihívásaihoz történő alkalmazkodás és az EU kereteibe illeszkedés.

- Szervezeti karaktere: elsősorban a városrégió léptékében megvalósított politikai-gazdasági koordináció. A korábbi hierarchikus adminisztratív struktúrák helyett a decentralizációval, regionalizációval jellemezhető új állami struktúrák fontos intézményes eszközöket kínálnak fel a régiószintü együttműködés erősítésére, amely jellemzően informális partnerségként működik, és az „urban governance” módszerét követi.

- Elméleti hátterét egyrészt az „új regionalizmus”, másrészt a posztfordizmus adja. Szemben az 1980-as években elterjedt „új lokalizmus” eszméjével, amely zéró végösszegü politikát jelentett a területi versenyképességben, az új típusú kormányzás intézményes ugródeszkaként fogja át a városrégiókon belüli kooperáció résztvevőit. A helyi gazdaságfejlesztés helyébe a regionális gazdaságfejlesztés lép. Ennek során az állam szerepe átértelmeződik, befolyást és ellenőrzést igyekszik gyakorolni a politikai-gazdasági folyamatok felett, ezért a nemzeti szintről kilép az internacionális és szupranacionális színtérre, ahol részt vesz a koordináció különféle szintjeinek alakításában.

- A hatalmi vonalak átrendeződése: Az ismételten virágzó nagyvárosi kormányzás olyan politikai-intézményes mechanizmusként is interpretálható, amelyen keresztül az állam területiségének szélesebb mértékű átalakulása megtörtént. Az államok területi szerkezetüket újraformálták (state restructuring, rescaling - Herrschel, Newman 2002) mind funkcionálisan, mind földrajzi értelemben. Ezt nevezik első lépésnek, a második lépést majd az új kormányzási reform (metropolitan governance) mint politikai stratégia adja. 
A folyamat értékeléséről többféle álláspont született. Néhány szerző a városrégiókban zajló intézményes átalakulási folyamatokat a regionalizmus reneszánszának, illetve abból következő evidenciának tartja. Ezek a szerzők arra a következtetésre jutottak, hogy a nemzeti szintű (elvi) közösséget mintegy felváltotta a regionális szinten megjelent „versenyképességi egység”, következésképp a szubnacionális szinten létrejött politikai aréna szereplői kiszorítják a területi szuverenitást birtokló nemzetállamot mint a kollektív politikai rend bázisát (Scott 1998). Ezzel az új kapitalista inváziót vizionáló állásponttal szemben létezik realistább kritikai megközelítés is, amelyik úgy fogalmaz, hogy a nagyvárosi térségeket érinto” reformok az egyenlötlen területi fejlődésnek és a területi polarizáció intenzívvé válásának kifejeződései (Brenner 2003).

Arról lenne szó, hogy az államok területi újjászerveződésének van egy szembetűnő „visszahierarchizálódási” tünete egy növekvő, sokszintű politikai építmény keretei között, amelyben a már meglévő és újonnan kreált intézményi szintek sokasága felé haladunk (multi-level governance). Tehát az 1990-es évektől kezdődően értékké vált az egyeztetés, az önkéntes együttműködés, a rugalmasság, a partnerség. Az állam új, szabályozott „tereket” (arénákat), szervezeti formákat és új kormányzási intézkedéseket hoz létre a nemzeti szint alatt és felett. Míg korábban a keynesi állam az ipar és a népesség egyenlő, kiegyensúlyozott szétterjedésében volt érdekelt a nemzetállam területén, addig az új államrezsim az ipari kapacitások, infrastrukturális beruházások szisztematikus koncentrálására tesz kísérletet a városrégiók és ipari körzetek támogatásával. Így próbál meg illeszkedni a változó nemzetközi környezethez.

\section{A városrégiók kooperációját erősító mechanizmusokról Az adminisztratív térfelosztás jelentőségének relativizálódása?}

A vázolt folyamat ellenére megállapítható, hogy az új kormányzásra épülő metodika nem szorította ki teljesen a városi térségek integrációját megvalósító bürokratikus közigazgatási szervezeti megoldásokat. Az EU területén változatlanul található több olyan városrégió, amelynek területe többé-kevésbé egybevág a területi közigazgatási határokkal (rendszerint a tartományi vagy régióhatárokkal), ami többféle előnnyel jár; többek között Madridról, Bilbaóról, Stockholmról, Bécsről, Brüsszelről, Hamburgról és Brémáról van szó. Az Európai Unió területi keretei között a városrégiók intézményesítési formáinak sokszínűsége érvényesül, számos esetben a korábbi szervezetek tovább- és egymás mellett élnek a governance típusú kooperációkkal. Sőt, némely esetekben a politikai legitimációval rendelkező városrégiók maguk alkalmazzák az új kormányzás eszközeit annak érdekében, hogy valamennyi szektor erőforrását egyesítsék adott régió versenyképességi pozíciójának erő- 
sítésére. ${ }^{10}$ Ennek oka, hogy a hagyományos és az új kormányzás tárgya eltér egymástól. Az utóbbi nyilvánvalóan nem terjedhet ki közhatalmi felhatalmazás alapján végezhető tevékenységekre, és kevéssé alkalmas szociális feladatok felvállalására. A hálózatokhoz viszont nem szükséges az önkormányzati/közigazgatási határok és a városi munkaerőpiac változó zónáinak illeszkedése. Ezzel egy régi probléma jutott nyugvópontra, mégpedig a városrégió határainak meghatározhatósága. A területi tervezés és a közigazgatás szempontjai statikus határokat követelnek, ugyanakkor a gazdaságfejlesztés előnyben részesíti a földrajzi variabilitást és rugalmasságot az intézményesítési szempontú statikussággal szemben. A gyakorlatban eltolódás tapasztalható az informális jellegü, laza szervezeti keretekkel is elégedett együttműködések javára, amelyek már nem céloznak adminisztrációs változásokat. Az új regionalizmus keretei között a nemzetállami várospolitikával rendelkező uniós tagállamok számára nem a szüken vett város a fontos (van den Berg, Braun, van den Meer 2007). Így Nagy-Britannia várospolitikájának területi dimenzióját nem a közigazgatási határok rajzolják meg, a kormány intézkedései a városi térségekre (urban areas) irányulnak. Franciaországban a szemléleti bázis szintén szélesebb, mivel az állam a régiókkal alkudozik, amelyek a források régión belüli allokációját végzik.

A 21. században a városrégiók intézményesítésének kérdése a normatív állam szempontjából nem elsősorban a közigazgatási határokhoz igazodás kérdéseként merül fel. Az agglomerációk mint funkcionális terek az állam számára a területi tervezésen keresztül irányíthatók, befolyásolhatók, azonban ebben a vonatkozásban sem kérhető rajtuk számon a NUTS-rendszer által kijelölt adminisztratív határokhoz való alkalmazkodás. Példaként említhető, hogy a német állam szabályozó hatalomként a szövetségi területrendezési törvényben (Raumordnungsgesetz) új tervtípust honosított meg. A területi tervezési jog új fejlődési lépcsőjét alkotja, hogy a tartományok felhatalmazást kaptak a központi államtól arra, hogy az agglomerációkra és más, a térstruktúra szempontjából fontos hálózatokra új tervtípust vezessenek be, a regionális területhasználati tervet. Ez olyan speciális dokumentum, amely egyszerre tölti be a regionális terv és az érintett önkormányzatok vonatkozásában a közös területhasználati terv funkcióját. Eljárásjogi és anyagi jogi szempontból egyidejüleg vonatkozik rá a tartományi tervezési és településrendezési törvény, így illeszkednie kell a tervek meglévő rendjébe. Ez az intézményi megoldás megspórol egy tervezési szintet az említett térségekben, valamint kezeli a városrégiók funkcionális határainak problémáját.

Hivatkozhatunk Olaszországra is, ahol 1990-ben a helyi önkormányzati reform eredményeként létrejöttek az új közigazgatási szintet megjelenítő, kétszintü irányítási struktúrájú metropolisztérségek. Ezeket (Milánó, Velence, Torino, Genova, Bologna, Firenze, Róma, Nápoly, Bari, Palermo, Catania) az érintett régiók jelölték ki, viszont igen fontos, hogy a metropolisztérség fogadja el az úgynevezett területi koordinációs tervet (piano territoriale di 
coordinamento). Az utóbbi tervtípus a stratégiai tervek közé tartozik, s koordinálja a térség valamennyi helyhatóságának gazdasági, területhasználati és környezet-igénybevételi terveit. A koordinációs terv illeszkedik a területi tervek rendszerébe, többek között összhangban kell állnia a régiók által elkészített regionális szintü koordinációs területi terv alapelveivel és célkitűzéseivel (Somlyódyné Pfeil 2005).

Az adminisztratív térfelosztás átértékelődését tükrözi, hogy számos esetben a közös kormányzást igénylő nagyvárosi térségek államhatárokat átlépő módon formálódnak, és államközi szerződések megkötését feltételezik. Sőt arra is van példa, hogy valamely policentrikus nagyvárosi térséget egész városrégiók alkotják, amelyek egymástól függetlenül léteznek, és közöttük a kooperáció igénye határon átnyúló jelleggel merül föl, anélkül, hogy tervezési-adminisztratív összenövésük egyelőre megvalósult volna. ${ }^{11}$

Tehát azt látjuk, hogy az agglomeráció egészére kiterjedő tervezési jogosultság döntő jelentőségű a fejlesztési irányok meghatározásában és a tervek végrehajtásában. Ezért gyakori, hogy a városrégiók regionális tervezési felhatalmazást kapnak, vagy speciális tervezési egységgé nyilvánítja őket a jogalkotó. Több nyugat-európai állam felismerte, hogy a tervezési jogosultság meglehetősen erőtlen eszköz, ha nem társul hozzá a megvalósítás eszközrendszere, legfőképpen a pénzügyi erő.

A városok gazdasági-társadalmi jelentősége nő a kormányzati politikákban is. A városrégiók kooperációs hajlandóságát az unió tagországaiban speciális támogatási programokkal szokták ösztönözni. Ez különösképpen jellemző a kifejezett várospolitikát meghirdető nemzeti kormányzatokra, így az Egyesült Királyságéra, Franciaországéra és Hollandiáéra, sőt Németországéra is, ahol a kompetenciák megoszlanak a szövetségi állam és a tartományok között. Ez többnyire pénzügyi alapok megnyitásával, kutatási programok és modellkísérletek meghirdetésével történik. Nemzeti várospolitikával nem rendelkező országokban rendszerint a területi tervezési politikán és az egyes ágazati politikákon keresztül befolyásolják a városfejlődést. Az 1990-es évektől kezdődően az észak-európai országokban megfigyelhető, hogy a regionális politikán belül érvényesülnek a városfejlesztés szempontjai, például Finnországban, ahol a kormány a városok részvételével munkabizottságot alakított egy várospolitika megfogalmazásának céljával, vagy Dániában, ahol a városok stratégiai hálózatainak megalapítását serkenti az állam (van den Berg, Braun, van den Meer 2007).

Az új uniós tagországok körében egy a nagyvárosi kormányzásról kialakult téveszmével bizonyosan érdemes leszámolni, mégpedig azzal, hogy az együttműködések az érintettek részéről önnön érdekeik felismeréseképpen spontán megszületnek, valamilyen szinten intézményesülnek. Arról az ismételt szervezeti burjánzásról, amely az 1990-es évek derekán kezdődött, s regionális tervezési kompetenciákat és adminisztratív hatalmat koncentráló új városrégiós szervezetek alapításához vezetett Bolognában, Stuttgartban, Hannover- 
ben és Koppenhágában, hamar kiderült, hogy egy rendkívül egyszerü recept működött. A helyi szereplők termékeként feltüntetett intézmények valójában fölülről kezdeményezett folyamatok eredményei voltak. Ezt Lefèvre (1998) úgy összegezte, hogy az együttműködések létrejöttéhez nem elegendő, hogy a kormányok a kooperációt egyszerủen ajánlják városaiknak, ahhoz intenzív ráhatásra van szükség, ahogy a francia állam a Communité Urban-t támogatja azzal, hogy a költségvetési források összességét a városrégióhoz utalja, amiről aztán a partnerek kénytelenek tárgyalni. Ezenfelül az állam még kiegészítő szubvenciókat is biztosít az együttmüködések erősítéséhez. Tehát a megváltozott környezetben is elengedhetetlen, hogy az állam proaktív módon ösztönözze a városrégiók szereplőit az együttműködések alapjainak megszilárdításban, többek között források feletti döntések átruházásával vagy éppen az együttmüködések intézményi kereteinek és a kapcsolódó felhatalmazásoknak felkínálásával.

A globalizáció égisze alatt súlyponteltolódás tapasztalható a kormányzási szintek között. Míg korábban a gazdaság szempontjából domináns területi szintnek a nemzetgazdaság számított, napjainkban három egyenértékủ területi szintről beszélhetünk: 1) a szupranacionális, 2) a nemzeti és regionális, 3) a lokális szintről. Egyértelműen megerősödött a szupranacionális integráció szerepe, amelynek egyik legfontosabb tényezője az EU (Lengyel 2010). Következésképp, amikor a városrégiók szabályozási környezetét vizsgáljuk, a nemzetállam mellett fokozott szerepet játszik az unió regionális politikája, amely tervezési-támogatási-finanszírozási mechanizmusokon keresztül nagymértékben alakítja Európa városhálózatának, benne a városrégióknak a fejlődését.

Az EU nem kapott felhatalmazást közösségi várospolitikára, az tagállami kompetenciába tartozik. Mégis megfigyelhető a városokra irányuló figyelem fokozódása a regionális politikán belül. Az unió kohéziós politikájában a területi kohézió és a városi dimenzió gyakorlatilag egy időben került a fókuszba. Már az 1990-es években számos eszköz irányult a városok fejlesztésére, emellett az unió több olyan kutatási programot is támogatott, valamint több olyan közösségi stratégiai iránymutatást is kibocsátott, amely az urbánus szemléletet erősítette. Az EU-nak döntő hatása volt a partnerség elvének alkalmazásában, a governance-nak mint új kormányzási módszernek az elterjesztésében, a funkcionális városi térség közös fogalmának kidolgozásában és meghonosításában. Ennek bizonyítására a közösségi eszköztárból csak néhány példát van módom kiragadni.

Ha az európai térség gazdaságának fejlődését és versenyképességét tartjuk szem előtt, akkor fontos állomásként említhető a Lisszaboni stratégia (2000), majd az Európai Bizottság dokumentuma (2006), amely a „Kohéziós politika és a városok: a városok hozzájárulása a régiók növekedéséhez és a foglalkoztatottsághoz" címet viselte. ${ }^{12}$ Ez utóbbi az aktuális időszakban az Európai Regionális Fejlesztési Alap prioritásai közé emelte a „governance”-t mint integrált megközelítést a fenntartható városfejlesztésben. A városi dimenzió formálódásának szintén mérföldköve volt a jelenleg megújítás alatt 
álló, 2007-ben elfogadott Területi agenda. A politikai dokumentum az EU várospolitikájának kulcselemei közé sorolta a kooperatív és hatékony governance-struktúrákat, $\mathrm{s}$ - többek között - kiemelte a partnerség horizontális és vertikális dimenzióját, továbbá a város- és regionális fejlesztés koordinált stratégiájának szerepét. A Lipcsei charta kimondta, hogy a városoknak át kell venniük az európai kohézióért viselt felelősséget.

Idesorolandók az ESPON-program kutatási eredményei, amelyek a policentrikus városhálózat létrehozását és a városhálózat kiterjesztését javasolják annak érdekében, hogy Európa új növekedési pályára állhasson. Az ESPON (1.1.1. projekt) vezette be a funkcionális városi térség fogalmát (FUAs), amely kategóriát a NUTS 3 területi szinten elemezték a kutatók. Bizonyos tagállamok - mint például Németország - kétségbe vonják az alkalmazott módszertan szakmai helytállóságát és nemzetközi összehasonlíthatóságát. Miután minden országban más a városnak és a hozzárendelt funkcióknak a definíciója, megkérdőjeleződik az adminisztratív NUTS 2-es és NUTS 3-as szintek használatának értelme (Göddecke-Stellmann, Porsche, Schmidt-Seiwert 2005). ${ }^{13}$ Az ESPON (2.3.2. projekt) a területi és városi kormányzás eszközeinek és gyakorlatának elemzését is elvégezte, és ajánlásaival letette a területi problémák megoldásához szükséges új kormányzás módszerének alapjait.

Az ESPON-hoz hasonlóan a RePUS (Regional Polycentric Urban System) ${ }^{14}$ program is a városok funkcionális térségeire (FVT) építette koncepcióját, amely a helyi munkaerő-piaci vonzáskörzet (Local Labor System) rendszerét jelölte ki alapul, és ezzel a foglalkoztatás térszervező szerepét priorizálta a lakóhely-munkahely elkülönülésből fakadó áramlásokat, az ingázást vizsgálva (Sütő 2008). Célja az volt, hogy Közép-Kelet-Európa közép- és kisváros-hálózatára alapozottan felvázolja a policentrikus fejlődés vízióját egy diffúz és kiegyenlítettebb fejlődési modell segítségével. Ezzel törekszik ösztönözni a funkcionális kapcsolatok létrejöttét és az integrációs folyamatot az új tagállamokban, ahol a rendszerváltás óta a területi koncentráció erősödése figyelhető meg. Nem feledkezhetünk meg az URBACT-programról (2002-2013), amely elsősorban a vállalkozásokra, az innovációra, a tudásgazdaságra, a foglalkoztatásra és a környezeti problémákra koncentrál. A fenntartható városfejlesztést támogató program rámutat arra, hogy a városfejlesztés összetett kérdés, amit három tématerülete kiválóan mutat: 1) a városok a növekedés motorjai és a munkahelyteremtés; 2) a társadalmi kirekesztés elleni küzdelem és a governance alkalmazása; 3 ) a városok és az integrált fenntartható fejlődés.

Összességében leszűrhető az a tanulság, hogy az EU kohéziós politikája több tekintetben a NUTS 2 régiók szerepének relativizálódása irányába hat. A versenyképességi célok megfogalmazása és a városok kisugárzó szerepének elismerése következtében a beavatkozásoknak már nem kizárólagos tervezési-megvalósítási léptéke a NUTS 2 régió. Az integrált városfejlesztés befogadására pedig a hagyományos programozási metódusok nem alkalmasak (Illés 2008). 


\section{A várostérségi kapcsolatok szabályozási környezete Magyarországon a rendszerváltástól napjainkig}

A rendszerváltás idején elfogadott önkormányzati törvény valamennyi integrációs csomópontot felszámolta a magyar közigazgatásban, az gyakorlatilag a településekre mint önkormányzati alapelemekre esett szét. A törvényben rendkívül érdekes a jogalkotói megközelítés, amely explicite egyetlen esetben sem állapit meg rendelkezést a városi vonzáskörzetekre vagy a város és környéke önkormányzatainak együttmüködésére. Ha továbbmegyünk e gondolatfonalon, akkor az is rögzíthető, hogy az önkormányzatok társulásáról szóló, 1997-ben elfogadott törvény sem ismer olyan speciális intézményt, esetleg agglomeráció- vagy városigazgatási modellt, amely a város és vonzáskörzete kooperációjának valamely viszonylatát szabályozná. A fóváros környéki (agglomerációs) társulás (ötv. 63/B. szakasza (2) bekezdés) az egyetlen önkéntes társulási forma, amely konkrétan megjelenik a törvényben. A törvényhozó azonban a lehetséges együttmüködési tárgykörök példálózó felsorolásával lezártnak tekinti a szabályozást 1994 óta, ezért a közigazgatás és különösen a közszolgáltatások terén a települések egymásrautaltságából keletkező feszítő problémák megoldására legfeljebb ágazati jellegű, egycélú társulási megállapodások jöttek létre a főváros és az agglomerációs önkormányzatok között. A tapasztalatok azt mutatják, hogy lényegében sem a központi, sem a lokális közigazgatási szintnek nem füződött érdeke a budapesti agglomeráció kormányzásának megoldásához.

Az erőteljesen prosperáló, 81 településből álló budapesti agglomeráció fejlődési irányainak orientációját számos nemkívánatos körülmény nehezíti. Az Országgyủlés 2005-ben elfogadta ugyan az agglomeráció területrendezési tervét, ez azonban a települési önkormányzati érdekek túlsúlyos érvényesülése következtében vajmi kevéssé tudja átfogó és közös érdekszféraként megjeleníteni az ország legnagyobb települési és gazdasági sürüsödési területét. Nem beszélve a nemzeti szintű területi célok érvényesíthetőségéről, annak érdekében, hogy Budapest mint nagyvárosi térség az európai térszerkezetben is stabilizálni tudja pozícióját. A törvény úgy is summázható, hogy az egalitárius önkormányzati szemlélet talaján elveszett a koncentrált települési és agglomerációs fejlődés lehetősége (Schuchmann 2007).

A kép teljességéhez hozzátartozik, hogy a budapesti agglomeráció területe statisztikai kistérségek által felszabdalt. A területükön megalakított többcélú kistérségi társulások az alapszintű közszolgáltatások megszervezésére és a kiegészítő állami támogatások lehívására predesztináltak, $\mathrm{s}$ inkább a térség széttöredezettségét, semmint egységét jelenítik meg. A többcélú társulások tevékenységét semmi sem fogja keretbe, a kistérségek közötti közigazgatási tartalmú egyeztetés vagy koordináció hiányzik. 
Ha az intézményesítés területfejlesztési szálán indulunk el, a területfejlesztésről szóló törvény előbb 1999-ben eltörölte, majd 2004. évi módosításával ismételten életre hívta a Budapesti Agglomerációs Fejlesztési Tanácsot. A törvényben felkínált szervezeti megoldásról megállapítható, hogy ugyancsak alkalmatlan a nagyvárosi tér egységes kormányzásának támogatására. A megyei területfejlesztési tanács mintájára megalakítható Budapesti Agglomerációs Fejlesztési Tanács kompetenciáján kívül reked a közigazgatás, s vele együtt kívül maradnak a közszolgáltatási feladatok. Felhatalmazása a területfejlesztési intézményrendszer leggyengébb láncszemével azonos. Egyébként is abszurd a hatályos szabályozás, miszerint a Fővárosi Önkormányzat Közgyülése és a Közép-magyarországi Régió Fejlesztési Tanácsa hozza létre a főváros és agglomerációja területén a főváros és a körülötte elterülő régió fejlesztési céljai, érdekei összehangolására (tft. 15/B.§) az agglomerációs fejlesztési tanácsot, amiben az agglomerációba tartozó önkormányzatok képviseltsége többszörös áttételeket szenved el. Mindent egybevetve (Tosics 2008) tényleges hatáskör és pénzügyi eszközök nélküli szervezetről van szó, amely hatályos fejlesztési dokumentummal sem rendelkezik. Ebben a helyzetben még konkurálnia is kell a Közép-magyarországi Régió Fejlesztési Tanácsával mint területi átfedésben lévő szervvel.

Ahhoz, hogy Budapest és agglomerációja mint nagyvárosi térség egyenrangú tagjává válhasson Európa metropolisz-hálózatának, sürgős felhatalmazást és támogatást kellene kapnia egységes kormányzási térré válásához. Ennek elmaradása és a fragmentáltságnak, valamint az önkormányzatok közötti versenyhelyzetnek a fennmaradása az egész ország versenyképességét veszélyezteti. Azt is mondhatjuk, hogy a városi kormányzás világszerte tapasztalható reneszánszának időszakában felkészületlenek vagyunk a városrégiós problematika kezelésére, holott a fővárost szolgáló társadalmigazdasági-környezeti viszonyok már megérettek az intézményesítésre. A többi (nagy)városi térségünk, amelyek közül csak hármat (pécsi, győri, miskolci agglomeráció) ismer el a statisztika agglomerációnak, vizsgálatokat igényel a kooperáció igényére és szükségletére vonatkozóan.

\section{Konklúziók}

Új regionális adminisztratív struktúrák és a nagyvárosi kormányzás új keretei jelentek meg a területi fejlődés támogatására az integrált Európai Unió égisze alatt. Ennek oka elsősorban az, hogy a tőke egyértelműen urbanizálódik, a régióközi kapcsolatokat jelentős részben a városrendszer közvetíti. Az európai integráció alapszerkezetét az európai nagyvárosi rendszer jelenti (Enyedi 1988). Az új regionalizmus ténylegesen „versenyképességi” regionalizmus, amely támogatja a városrégió ideáját mint a nemzeti gazdaság vezető csopor- 
tosulását. Így az 1990-es évektől kezdődően az európai városok fokozatosan a gazdasági és monetáris integráció kulcsszereplőivé váltak.

A vizsgált folyamatok összegzéseképpen arra a következtetésre juthatunk, hogy az állam szerepe és szerepvállalása valóban változáson ment át. Hosszú időn keresztül az állam szinonimája volt a szuverénnek, s az államot azonosították a szabályozó hatalommal. Azonban látható, hogy a weberi koncepció mára tarthatatlanná vált, mivel az utóbbi évtizedekben a szabályok mind erősebben konszenzuson alapulnak, nem pedig legitimációs kényszeren. Az állam többé nem egységes és koherens területi hatalom, hanem folyamatos formálódáson megy keresztül (Varró 2010). Az állam területi átrendeződésének kísérőjelensége az új kormányzás (governance) megjelenése, amely mint önigazgató társadalmi kormányzás a piactól átvett hagyományos hierarchikus és kooperatív módszereket egyaránt alkalmazza (Somlyódyné Pfeil 2008).

Végső soron a nagyvárosi reformokban felismerhető az állam „szelektív” területisége, aminek többféle megnyilvánulását lehet elkülöníteni (Brenner 2003): az állam nemzetköziesedése, nemzeti jellegének gyengülése vagy elvesztése, továbbá az államtalanítás. Az utóbbiba illeszkedik a partnerség különféle formáinak megjelenése, továbbá a nem-kormányzati szereplők és a paraállami intézmények, ügynökségek térnyerése, amelyek növekvő mértékben látnak el állami funkciókat különféle területi léptékekben. Nem tagadható, hogy e jelenségek kibontakozását az Európai Unió mint szupranacionális politikai intézmény lényegesen befolyásolta, mondhatni erősítette.

Mindezek tükrében joggal merül fel a kérdés, hogy az elmúlt húsz évben hazánk milyen választ adott a nemzetközi kihívásokra. Magyarországon a rendszerváltástól kezdődő időszakot a várospolitika hiánya jellemezte, a városok nem kaptak figyelmet sem a közigazgatásban, sem a területpolitikában. Az új Országos területfejlesztési koncepció ${ }^{15}$ adott először figyelemre méltó válaszokat a városi térségek kezelésére, lényegileg egy szakmai szempontból tetszetős policentrikus városhálózati modell jövőképének megfogalmazásával. Az OTK-ban a törvényhozó hét országos területi cél közül kettőt a városhálózatra vonatkoztat: az egyik a versenyképes budapesti metropolisztérség megteremtése, a másik a regionális innovációs pólusok és városhálózati kapcsolatrendszerek fejlesztése - alközpontok és tengelyek harmonikus rendszerének létrejötte. Sőt, kiegészítőleg az intenzív város-vidék-viszony kialakítása is megjelenik azzal a céllal, hogy a központszerepet betöltő városok tágabb környezetükkel funkciómegosztáson alapuló kapcsolatokat hozzanak létre. A megvalósítás eszközeit tekintve már kétségeket ébreszt a dokumentum, mivel az agglomerációk különféle szereplőinek partneri együttműködését, menedzsmentszervezetek létrehozását nevezi meg, illetve pusztán annyit mond, hogy törekedni kell az összes érintett település agglomerációs externáliákat kezelni képes intézményi kooperációjának biztosítására. Ebből a megközelítésből azonban nem állapítható meg, hogy kinek a felelőssége létrehozni a végrehajtási struktúrákat, még kevésbé az, hogy azokban az állam milyen sze- 
repet fog vagy kíván vállalni. Következésképp az agglomerációk, de még a várostérségi kapcsolatok intézményesítésére alkalmas és adekvát szervezeti formák is teljességgel hiányoznak a hazai szabályozási környezetből.

Tapasztalatok bizonyítják, hogy sem az együttmúködési struktúrák, sem a hálózatok nem fognak létrejönni azért, mert a „szabályozó állam” azt egy jogi dokumentumban előírta. Nem tudható, hogy mikor jön el a számvetés ideje, az azonban bizonyos, hogy az eltelt öt év alatt nem teljesültek a célok. Hazánkban mint megannyi terv, az OTK-nak ez a része is terv maradt. Ez tágabb nézőpontból is értekelhető (Varró 2010), hiszen az újólag megjelent városcentrikus retorikát nem követte végrehajtás városcentrikus állami beavatkozások formájában. Noha az elmúlt húsz évben folyamatos állami reformnak voltunk tanúi, nyilvánvaló, hogy az állam területi szerkezete körüli küzdelem ma már nem egyszerüsíthetö le az állam kinyilatkoztatásaira, hanem szükség lenne a különféle szintü területi közösségek állásfoglalására, a velük történő eszmecserére.

Hazánknak az Európai Unióba való belépésével egyúttal azzal is számot kell vetni, hogy városhálózatunk minden tekintetben részesévé vált az európai városversenynek, amire a közigazgatásnak és a területfejlesztésnek megfelelő válaszokat szükséges adnia. Az állam nem menthető fel a felelősségvállalás alól. Hosszú ideje külső és belső igény mutatkozik arra, hogy a magyar kormányzat rendelkezzék koherens várospolitikával. Kívánatos lenne, hogy a városállományt mint hálózatot tekintse, mi több, annak irányításához hozzárendelje a tervezési-szabályozási, finanszírozási-támogatáspolitikai eszközöket, súlypontokat jelöljön ki, és határozza meg viszonyát a különféle ágazati politikákhoz (gazdaságpolitika, közlekedéspolitika, lakáspolitika, szociális politika, környezetpolitika stb.). A hiány jelenségére számos magyarázatot találhatunk, azonban mint átfogó problémára a kormányzás elégtelenségére, alacsony hatékonyságára érdemes ráirányítani a figyelmet. Vitathatatlan, hogy Magyarország erősen centralizált állam, azonban még ehhez képest is sajátos jellemzője a politika „túlhatalma”. Értve ezen, hogy a központi kormányzat nem hajlandó a társadalmi intézményrendszer alsóbb szintjeire feladatokat és erőforrásokat leadni, nem kíván a társadalmi erőkre támaszkodni, miáltal maga is alulteljesít, és egyidejűleg korlátozza a társadalmi szereplők működését. Így az állami és társadalmi kapacitás egymást gyengítően hat, ahelyett, hogy egymást erősítenék (Hosszú 2010). Nehezíti a helyzetet az államműködés zavara, amely nem engedi érvényesülni azt az elvet, miszerint a modern állam elkülönült társadalmi alrendszer, legalábbis formálisan. Valójában a mai magyar állam sajátos összenövésben van más alrendszerekkel. Sajó András megfogalmazásában az állam a gazdaság és a társadalmi élet szinte minden szegmensének szerves része. Ez az államszervezet alacsony hatékonyságú, s ez a körülmény az átlagosnál rosszabb egyensúlyi állapothoz vezet. A közérdek elsikkad vagy általában meg sem tud fogalmazódni, mivel nem léteznek hosszú távú szakpolitikák (Sajó 2008). A magyar állam válsága sajnálatos módon nemcsak gazdálkodási, hanem komplex, az 
állam cselekvőképtelensége és válsága rátelepszik a gazdaságra, sőt benyomul a társadalmi térbe (Gellén 2010).

A rendszerváltás, majd az uniós csatlakozás óta fokozottan nehezedik ránk a nyomás, amely megfelelő intézményi és humán kapacitások kiépítését várja el tőlünk az „europaizáció” égisze alatt. Ennek teljesítésében - más rendszerváltó államok társaságában - mindig is a minimumra törekedtünk (Ágh 2005), vagy egyenesen az állam működésének zavarai, saját korlátai eddig a határig engedték a reformokat, az alkalmazkodást. A decentralizáció és integráció (mint modern államszervezési elvek) érvényesülésének kérdése minduntalan felvetődik, majd hamvába hull. Az európai tendenciákra figyelemmel feltehetőleg a magyar állam modernizációja érdekében, sőt az egyre gyakrabban elhangzó innovativitás és versenyképesség iránti igény nézőpontjából is elkerülhetetlen lenne az ország kormányzási képességét a nagyvárosi térségek kérdéskörével összhangban megvizsgálni, majd egy a szakpolitikák által támogatott megvalósításorientált várospolitikát kialakítani.

\section{Köszönetnyilvánítás}

A tanulmány a 81789 azonosító számú OTKA-kutatás keretében íródott (Cím: Az agglomerációk intézményesítésének sajátos kérdései a közigazgatási struktúrán innen és túl. Vezető kutató: Somlyódyné Pfeil Edit.).

\section{Jegyzetek}

1 A városrégiók közös külpolitikájához szokás sorolni a regionális gazdaságfejlesztést, valamint a közös regionális marketinget és menedzsmentet. Hiszen nemcsak államszervezési szempontból adott térben kénytelenek tevékenykedni, hanem egy olyan gazdasági térben is, amelyben az interkommunális együttműködések új vonulata (építési területek, ipari parkok, innovációs transzferközpontok stb. közös kialakítása) markánsan kifejezésre jut.

2 A metropolisz-régiók lehatárolásának speciális módszertana létezik, amely - többek között - metropolisz-funkciók (gazdasági, politikai és egyéb döntési és kontrollfunkciók, gazdasági-technikai és társadalmi-kulturális innovációs és versenyképességi funkciók, gatewayfunkciók meglétét és sűrűségét vizsgálja a nagyvárosi térségek esetében. Legújabban megtörtént az európai metropolisztérségek lehatárolása, mely 125 metropolisz-régiót ismer el négy különböző típus megkülönböztetése mellett. A közölt ragsorba hazánkból egyetlen városként Budapest került be a 23. ranghelyet elfoglalva (BBSR 2011).

3 Helyszűke okán ezúttal le kell mondanom a kelet-közép-európai térség országaiban lezajlott és zajló folyamatok átfogó bemutatásától, azonban a dolog fontosságára tekintettel egy későbbi tanulmányban majd sort kerítek rá.

4 Példák a nagyvárosi politikai szervezetek nagyméretű bürokratizált formáira: Greater London Council (1963), Madrid Metropolitan Area Planning and Coordinating Comission(1963), Greater Rotterdam Port Authority (1964), Communates urbaines (városközösségek) Franciaországban (Bordeaux, Lille, Lyon, Strasbourg 1966), Regionalverband Stuttgart (1972), Metropolitan counties Nagy-Britanniában (Manchester, Birmingham, Liverpool, Leeds, 
Sheffield, Newcastle 1974), Cormoració Metropolitana de Barcelona (1974), Greater Copenhagen Council (1974), Umlandverband Frankfurt (1974), Kommunalverband Ruhr (1975).

Pénzügyi szempontból mindenképpen kézenfekvő és optimális megoldás az agglomerációnak egységes térként kezelése és az állami pénzügyi kiegyenlítési politikába történő beillesztése. Hiszen a központi város saját lakosságán túl vonzáskörzetét is ellátja (köz)szolgáltatásokkal, viszont az agglomeráción belüli ingázásnak természetes következménye, hogy a közszolgáltatások biztosításának és az adójövedelmek keletkezésének helye elválik egymástól. Amikor a városmag szolgáltatásait „idegenek” is igénybe veszik, a keletkező túlcsorduló hatást valakinek ellentételeznie kell. Lényegében az ún. használati „spillover-hatás” ellensúlyozásának alkalmas kereteivé váltak az agglomerációs együttműködések. A „spillover-hatás” emellett zavart idéz elő az össztársadalmi források hatékony allokációjában, hiszen a városközpontnak terveznie kell a szolgáltatásszervezést és -fejlesztést. Ez a szempont a nagyvárosi tér szintjén a kezdetektől összefügg az integrált és egységes tervezés megvalósításával, a területhasználat koordinációjával (Somlyódyné Pfeil 2003).

6 Közöttük megtalálhatók voltak az állam általános területbeosztásába beillesztett és a szubnacionális szint ragjára emelt szervek éppúgy, mint a speciális státussal alapított szervezetek, sőt megjelentek köztük az önkormányzati társulások is. Csoportosíthatók voltak a szervek egyszintű integrált egységekre, legtöbbször önkormányzati státussal, és kétszintű kormányzási szervezetekre, amelyek felső szintjén az agglomerációt képviselő szervezet jelent meg. Ez utóbbiak legitimációjának erőssége attól függött, hogy delegált vagy közvetlen választással létesített szervekről volt-e szó. Végül voltak az ún. koordinatív típusú laza intézmények, amelyek nélkülözték a közhatalmi karaktert.

7 Ismert ez a tény Nagy-Britanniára vonatkozóan, hiszen Margaret Thatcher miniszterelnökségéhez, az olajválsághoz, illetve az azt kísérő pénzügyi válsághoz kapcsolódó állami politikai liberalizációhoz kötődik. Az angol kormány 1986-ban az MCC-ket, vagyis a metropoliszok megyei tanácsait mint a lokális önkormányzatok szükségtelen és felesleges szintjét szüntette meg. A döntés két területre hivatkozott, amelyeken indokolatlanul magasak voltak a kiadások, mégpedig a gazdaságfejlesztésre és a stratégiai tervezésre. Ez azért meglepő, mert az agglomerációk fejlesztési tervezése az 1960-as és 1970-es években még különösen divatos volt (Leach et al. 1990). 1006/1971. (III. 16.) Korm. sz. határozat a területfejlesztés irányelveiről. 1007/1971. (III. 16.) Korm. sz. határozat az országos településhálózat-fejlesztési koncepcióról. KSH (1986): Területi statisztikai évkönyv, 1985. KSH, Budapest.

10 Elég arra a kutatásra utalni, amelyet Németország 15 nagyvárosa regionális együttműködési szervezetének beazonosítására folytatott a Brémai Egyetem. A kutatók négy szervezeti típust különítettek el, amelyeken felül értelmeződnek az ún. governance-struktúrák (Prigge 2006). Az ezredforduló történései bizonyították, hogy az önkormányzatok horizontális kooperációs szándéka által kiérlelt és a tartományi törvényhozás által támogatott, területileg egységes, politikai legitimációval bíró regionális szövetségek és városrégiók továbbra is életképesek (Stuttgart, Hannover). Sőt, a keleti tartományokban Lipcse és Drezda példája igazolja, hogy a községek beolvasztása megfelelő helyspecifikus közvetlen részvételi formák garantálása mellett még mindig szervezeti alternatívát jelent a várostérségi együttműködésben.

11 A Rajna-Majna nagyvárosi régió lényegét a tudásintenzív szolgáltatóvállalatok telephelyi hálózata határozza meg, amely hat beazonosítható funkcionális városi térségből (functional urban region) áll Frankfurt, Wiesbaden, Mainz, Darmstadt, Hanau és Aschaffenburg magterületekkel, ami három német tartomány területét érinti.

12 Cohesion Policy and cities: the urban contribution to growth and jobs int he regions (EC 2007-2013).

13 A német területi szakma szerint az alkalmazott területi kategória nem engedi a német városhálózat jellemzőinek hủ visszatükrözését, a torzítást mi sem bizonyítja jobban, mint hogy az ESPON-eredmények szerint Magyarországon vagy Olaszországban fölülreprezentált az egy NUTS 3-as egységre eső funkcionális városi térségek száma, ami azt a látszatot kelti, mintha Magyarország policentrikusabb és fejlettebb városhálózattal rendelkezne, mint Németország. 
14 A regionális policentrikus városrendszer stratégiája Közép-Kelet-Európa gazdasági integrációs térségében. INTERREG III B CADSES kutatási projekt. 97/2005. (XII. 25.) OGY határozat.

\section{Irodalom}

Ágh A. (szerk.) (2005): Institutional Design and Regional Capacity-Building in the Post-Accession Period. Hungarian Centre for Democracy Studies, Budapest

Balázs I. (1988): Az agglomerációigazgatás szervezeti és működési rendszerei (Nemzetközi kitekintés). MTA Államtudományi Kutatások Programirodája - Fővárosi Kutatócsoport, Budapest

Beluszky P. (1987): A középszintü igazgatás és hazánk térszerkezete. Regionális Kutatások Központjának Kutatási Eredményei. MTA RKK, Pécs

van den Berg, L., Braun, E., van der Meer, J. (2007): National Policy Responses to Urban Challanges in Europe. ERICUR series. Ashgate, Aldershot

Brenner, N. (2003): Metropolitan Institutional Reform and the Rescaling of State Space in Contemporary Western Europe. European Urban and Regional Studies 10 (4), 297-324.

Csefkó F., Rechnitzer J. (1979): Az agglomeráció-kutatás módszertani kérdései. Területi Statisztika, 1., 65-68.

Enyedi Gy. (1988): A városnövekedés szakaszai. Akadémiai Kiadó, Budapest

Enyedi Gy. (1992): Urbanizáció Kelet-Közép-Európában. Magyar Tudomány, 6., 685-693.

Erdősi F. (2003): Globalizáció és a világvárosok által uralt tér II. Tér és Társadalom, 4., 1-16.

Ereky I. (1936): Közigazgatási reform és a nagyvárosok önkormányzata. Statisztikai Közlemények, (Budapest Székesfőváros Statisztikai Hivatala)

Europarat (1976): Kommunale Verwaltungsreformen in Europa. Verlag W. Kohlhammer, Köln

Fürst, D. (1991) Stadt und Region in Verdichtungsräumen. In: Blanke, B., Beuzler, S. (Hrsg.): Staat und Stadt. Westdeutscher Verlag, Opladen, 93-112. (Politische Vierteljahresschrift; Sonderheft 22.)

Gellén M. (2010): Ha válság, akkor reform. Kalandozások a közigazgatási reformok forrásvidékén. In: Gellén M., Hosszú H. (szerk.): Államszerep válság idején. Magyary Zoltán emlékkötet. Complex Kiadó Kft., Budapest, 49-62.

Göddeke-Stellmann, J. et al. (Eds.) (2011): Metropolitan areas in Europe. BBSR-Online Publikation, 1.

Göddecke-Stellmann, J., Porsche, L., Schmidt-Seiwert, V. (2005): Den Blick Schärfen. Eine kritische Bestandsaufnahme des Konzepts funktionaler Stadtregionen im ESPON-Programm. Informationen zur Raumentwicklung, 7., 457-464.

Gründler, W. (1974): Kommunale Gebietsreform in den Verdichtungsgebieten der BRD - Unter besonderer Berücksichtigung der Parteipolitischen Kompontente. Reinische Friedrich-Wilhelm Universität, Bonn

Hencz A. (1976): Területrendezési törekvések Magyarországon. Közgazdasági és Jogi Könyvkiadó, Budapest

Herrschel, T., Newman, P. (2002): Governance of Europe's City Regions. Routledge, London

Horváth M. T. (2002): A helyi közszolgáltatások szervezése. Dialóg Campus Kiadó, Budapest-Pécs

Horváth M. T. (2008): Urbanizáció, igazgatás és pénzügyi föderalizmus. Tér és Társadalom, 1., $125-140$.

Horváth M. T. (2011): Nem boldogít. Az önkormányzati vagyon problémái. Jogtudományi Közlöny, 2., 77-90.

Hosszú H. (2010): Az állam szerepe a kormányzásban. In: Gellén M., Hosszú H. (szerk.): Államszerep válság idején. Magyary Zoltán emlékkötet. Complex Kiadó Kft., Budapest, 199-219.

Illés I. (2008): „A területi kohézió” és a városfejlesztés. Kutatási zárótanulmány (kézirat). MTA Regionális Kutatások Központja, Pécs

Jørgensen, G., Aerø, Th. (2008): Urban Policy in the Nordic Countries - National Foci and Strategies for Implementation. European Planning Studies, 1., 23-41.

Józsa Z. (2006): Önkormányzati szervezet, funkció, modernizáció. Dialóg Campus Kiadó, Budapest-Pécs 
Keating, M. (2001): Rethinking the region: Culture, Institutions and Economic Development in Catalonia and Galícia. European Urban and Regional Studies, 3., 217-234.

Kilényi G. (1985): A településegyüttesek igazgatásának szervezeti formái és módszerei. In: Rechnitzer J. (szerk.): Vonzáskörzetek - Agglomerációk II. Akadémiai Kiadó, Budapest, 127-154.

Kőszegfalvi Gy. (1985): A magyarországi településrendszer strukturális változása. In: Rechnitzer J. (szerk.): Vonzáskörzetek - Agglomerációk II. Akadémiai Kiadó, Budapest, 31-54.

Kuindersma, W., Boonstra, F. G. (2010): The changing role of the state in Dutch regional partnerships. Government and Policy, 6., 1045-1062.

Kühn, M. (2001): Regionalisierung der Städte. Raumforschung und Raumordnung, 5-6., 402-411.

Leach, S., Davis, H., Game, Ch., Skelcher, Ch. (1990): After Abolition The Operation of the Post-1986 Metropolitan government System in England. INGOLOV, The University of Birmingham, Birmingham

Lefèvre, Ch. (1998): Metropolitian Government and Governance in Western Countries: A Critical Review. International Journal of Urban and Regional Research, 1., 9-25.

Lengyel I. (2003): Verseny és területi fejlődés: térségek versenyképessége Magyarországon. JATEPress, Szeged

Lengyel I. (2010): Regionális gazdaságfejlesztés. Versenyképesség, klaszterek és alulról szerveződo” stratégiák. Akadémiai Kiadó, Budapest

Lengyel I., Rechnitzer J. (2004): Regionális gazdaságtan. Dialóg Campus Kiadó, Budapest-Pécs, (Területi és Települési Kutatások; 26)

Pálné Kovács I. (2006): Helyi-területi önkormányzati rendszerek. In: Tóth J., Legény K. (szerk.): Összehasonlitó alkotmányjog. Complex, Budapest

Perger É. (1999): Közigazgatási dilemmák. In: Barta Gy., Beluszky P. (szerk.): Társadalmi-gazdasági átalakulás a budapesti agglomerációban I. Regionális Kutatási Alapítvány, Budapest, 181-224.

Prigge, R. (2006): Regionale Kooperation aus der Sicht der größten deutschen Städte. In: Kleinfeld, H. Plamper, H., Huber, A. (Hg.): Regional Governance Band I. V\&R Unipress, Göttingen, 133-144.

Rechnitzer J. (szerk.) (1985): Vonzáskörzetek - Agglomerációk II. Akadémiai Kiadó, Budapest

Rechnitzer J., Lados M. (2004): A területi stratégiáktól a monitoringig. Dialóg Campus Kiadó, Budapest-Pécs

Sajó A. (2008): A társadalom működési zavarai és az államgépezet. Állam- és Jogtudomány, 3., 233-280.

Schuchmann P. (2007): Kompromisszumok és engedmények. A Budapesti agglomeráció terve keretbe foglalja a jövő döntéseit. Falu Város Régió, 2., 34-40.

Scott, A. J. (1998): Regions and the World Economy. Oxford University Press, London

Sinz, M. (2005): Metropolregionen. Einführung. Informationen zur Raumentwicklung, 7., 1-4.

Somlyódyné Pfeil E. (2003): Önkormányzati integráció és helyi közigazgatás. Dialóg Campus Kiadó, Studia Regionum, Budapest-Pécs

Somlyódyné Pfeil E. (2003a): Paradigmaváltás az önkormányzatok közötti együttműködésben. Város vagy régió? Jura (a PTE Állam- és Jogtudományi Karának tudományos lapja), 2., 106-113.

Somlyódyné Pfeil E. (2005): A városok az átalakuló közigazgatási rendszerekben és a területi politikában. Magyar Közigazgatás, 4., 193-203.

Somlyódyné Pfeil E. (2008): A városi térségek a közigazgatási struktúra és a governance keresztmetszetében. Tér és Társadalom, 1., 27-43.

Stern, K., Püttner, G. (1968): Grundfragen zur Verwaltungsreform im Stadtumland Empfehlungen zur Neuordnung von Ballungsgebieten, dargestellt am Großraum Hannover. Verlag Franz Vahlen $\mathrm{GmbH}$, Berlin-Frankfurt am Main

Sütő A. (2008): Város és vidéke rendszerek és típusaik Magyarországon. Falu Város Régió, 3., 51-64. Szoboszlai Gy., Wiener Gy. (1978): A város szerepe a középszintủ területi igazgatásban. Budapest, Kézirat

Territorial Agenda of the European Union (2007): Towards a More Competitive Europe of Diverse Regions. (To be presented for adoption by Ministers responible for Territorial Development on the occasion of the Informal Ministerial Meeting to be held in Leipzig on 25 May 2007.)

Tosics I. (2008): Nagyvárosi kormányzás: a város és környéke együttműködése. Külföldi példák és a hazai relevancia. Tér és Társadalom, 1., 3-25. 
Varró K. (2010): After Resurgent Regions, Resurgent Cities? Contesting State Geographies in Hungary and England. Radboud University, Nijmegen

Verebélyi I. (1993): Kis- vagy nagyméretủ alapszintű önkormányzatok. Magyar Közigazgatás, 4., 193-205.

Weck, S. (1995): Neue Kooperationsformen in Stadtregionen - Eine regulationstheoretische Einordnung. Dortmunder Beiträge zur Raumplanung 74. Institut für Raumplanung (IRPUD) Universität Dortmund, Dortmund

Zehetner, F. (ed.) (1982): Reformen der Kommunen und Regionen in Europa. Institut für Kommunalwissenschaften und Umweltschutz, Linz 